\title{
História, teoria social e método de investigação de perpetradores no Nacional- Socialismo: um estudo sobre tipologias ${ }^{1}$
}

Helgard Kramer $^{2}$

Resumo: Este artigo analisa resultados da pesquisa social e histórica sobre perpetradores no Nacional-Socialismo, focando especialmente a atuação e as biografias de médicos da SS em Auschwitz. Verificou-se que importantes marcos na pesquisa foram determinados por arranjos entre os gêneros na Alemanha nazista, em que homens (e mulheres) foram biograficamente situados em termos de relações autoritárias (formuladas pela teoria do caráter autoritário da Escola de Frankfurt). A pesquisa revelou que não há apenas um tipo de perpetrador do holocausto. Motivações, atitudes e comportamentos dos perpetradores foram avaliados a partir de um modelo de interpretação que identificou severas deformações na socialização profissional de médicos (e de outros grupos ocupacionais) atuantes no Nacional-Socialismo, ao lado de uma específica ausência de autonomia política, característica da mentalidade alemã. Ao reconstruir aspectos históricos da sociedade alemã e descrever diferentes tipos de perpetradores a partir de uma perspectiva interdisciplinar, este artigo discute a aplicação e o valor explicativo dessas tipologias.

Palavras-chave: Médicos no Nacional-Socialismo; Tipologias de perpetradores no Nacional-Socialismo; Gênero e Nacional-Socialismo; Socialização profissional,; autoritarismo e cultura política na Alemanha nazista.

\section{History, social theory and methods of research on perpetrators during National} Socialism: a study of typologies

\begin{abstract}
This article analyzes the results of social and historical research on perpetrators in National Socialism, focusing especially on the performance and biographies of SS doctors in Auschwitz. It was found that important boundary conditions were a specific gender arrangement in NS-Germany, where these men (and women) were biographically situated in, as well as authoritarian relationships (at the time formulated by the authoritarian character theory of the Frankfurt School). But there is not just one type of perpetrator of the Holocaust. Motivation, attitudes and

1 Agradeço a Maike Dietrich, Stefan Friedrich, Roger Naegele e Iris Wachsmuth pelos comentários críticos a este texto. A versão em português do texto sofreu pequenas reduções e alguns acréscimos e sua tradução do alemão foi feita por Arim Soares do Bem.

${ }^{2}$ Helgard Kramer é professora do Instituto de Sociologia da Universidade Livre de Berlim. EMail: $\underline{\text { hkramer@zedat.fu-berlin.de }}$
\end{abstract}

Latitude, Vol. 1, no2, pp.07-46, 2007. 
behaviour of the perpetrators is evaluated from a model of interpretation that identifies severe deformations in the professional socialization of physicians (and other occupational groups) working under National Socialism, next to a specific lack of political autonomy characteristic of the German coetaneous mentality. By reconstructing the historical aspects of German society, and describing different types of perpetrators from an interdisciplinary perspective, this article discusses the application and explanatory value of these typologies.

Key words: Physicians in National Socialism; Typologies of perpetrators in National Socialism; Gender arrangement in NS-Germany; Professional socialization; authoritarian relationships and political culture in NS-Germany.

\section{Introdução}

A ciência da história relacionada à pesquisa sobre perpetradores no NacionalSocialismo (NS-Täterforschung) constitui uma ciência-chave. Aos resultados da pesquisa histórica sobre o Nacional-Socialismo devem se relacionar todas as demais disciplinas, assim como todos os seus questionamentos precisam, primeiro, refletir sobre a compatibilidade com o "saber assegurado" da pesquisa histórica. Que também aqui evidentemente saberes factuais submetem-se à interpretação, ou seja, que "fatos científicos" (LUDWIK FLECK) sejam, eles próprios, produzidos, não facillita em nada o posicionamento a respeito. Por outro lado, as controvérsias inerentes a cada disciplina são, na República Federal Alemã, enormemente sobredeterminadas por interesses políticos e morais, de modo análogo a outras sociedades européias, nas quais resistência e colaboração foram igualmente objeto de instrumentalização política e concorrem, pois, para uma diferenciação entre fases de ocultamento apologético e de enfrentamentos críticos (DUBIEL, 1999; MATTIOLI, A., 2005). Evans (2003) estabeleceu diferenças entre três fases da pesquisa histórica sobre o Nacional-Socialismo. Uma primeira, a partir da qual a base de massas do sistema do Nacional-Socialismo foi sistematicamente ofuscada; uma segunda, a partir da qual se consolidaram as teses institucionalizadas e que alimentaram o paradigma funcionalista da ciência da história na terceira fase da pesquisa sobre a política destrutiva do Nacional-Socialismo.

\section{Resultados da pesquisa disciplinar com perpetradores}

Uma dificuldade para a integração de resultados disciplinares parciais resulta do fato de ser, com freqüência, um conceito de agente (Täterbegriff) claramente definido, mas estreito do ponto de vista jurídico e insuficiente para a descrição da

Latitude, Vol. 1, no2, pp.07-46, 2007. 
divisão do trabalho relacionada ao genocídio. Neste sentido, o historiador Dieter Pohl fala de "aparelhos de perpetradores" (Täterapparat) para descrever a convergência entre SS, SD, Wehrmacht e sociedade civil alemã na Polônia ocupada. Em sociologia o agente, ou a agente, pressupõem uma concepção teórica da ação relacionada ao indivíduo, resultando da concorrência de fatores como orientações para a ação, necessidades e interesses acoplados a expectativas do contexto, que têm como conseqüência decisões e comportamentos específicos. A partir dessa óptica trata-se, então, de perseguir motivos inscritos nas histórias de vida em perspectiva biográfica, de modo a poder expor de modo diferenciado as distintas formas de participação, construindo-se um quadro da real combinação da participação envolvendo perpetradores, ajudantes, cúmplices, espectadores e não-participantes do genocídio no Nacional-Socialismo. ${ }^{3}$

Se observarmos uma disciplina como a Psicologia, é visível que ela pareça não oferecer resultados. Um estudo de psicólogos que tiveram a oportunidade de investigar os chamados "perpetradores principais" ("Haupttäter") no processo de Nuremberg somente foi publicado com 50 anos de atraso (ZILLMER et al., 1995). Gilbert, Kelley e outros psicólogos investigaram esses réus com as mais avançadas baterias de testes psicológicos disponíveis na ocasião, principalmente o TAT (Thematic Apperception Test $^{4}$ e o Rohrschach-Test ${ }^{5}$, tendo hesitado por longo período em publicar os seus resultados, uma vez que chegaram à conclusão de que os criminosos de guerra denunciados em Nuremberg, considerando-se a sua estrutura psíquica, eram pessoas não-patológicas, ou seja, absolutamente normais. À exceção de Streicher, cujo antisemitismo continha elementos paranóicos - e isso se pode constatar através da leitura de Stürmer ${ }^{6}$ - esses membros da elite do Nacional-Socialismo eram, em sentido psicológico, normais e consideravam, eles próprios, Streicher como sendo um louco ${ }^{7}$. Uma vez que esses acusados demonstraram possuir estruturas de personalidade completamente normais ("normale Persoenlichkeitszuege"), eram discretos e capazes de

\footnotetext{
${ }^{3}$ Assim, já em 1966, Jean Améry argumentou, contra forte reação na esfera pública, sobre a tese da culpa coletiva dos alemães: "Culpa coletiva. Isso é naturalmente coisa sem sentido se aí está implícito que a comunidade dos alemães têm uma consciência comum, uma vontade comum, uma iniciativa comum para a ação e seriam, por decorrência, cupados. Mas é uma hipótese útil se a gente não entende outra coisa senão a soma manifestamente objetiva de um comportamento individual de culpa. Então a culpa de cada alemão individualmente - culpa da ação, culpa da omissão, culpa da fala, culpa do silêncio - torna-se a culpa integral de um povo". Cf. Amery, J., 1990, p. 117.

${ }^{4}$ O TAT (Teste de Percepção Temática) é um teste de projeção psicológica que objetiva revelar aspectos reprimidos da personalidade, motivos e necessidades dos que a ele se submetem. Foi desenvolvido pelos psicólogos Henry A. Murray e Christina D. Morgan durante os anos 30 na Universidade de Harvey para explorar dinâmicas subjacentes da personalidade (N.T.)

${ }^{5} \mathrm{O}$ teste de Rorschach foi desenvolvido pelo suiço Hermann Rorschach para possibilitar que pacientes relutantes pudessem descrever seus processos de elaboração mental (N.T.)

${ }^{6}$ Streicher foi um proeminente nazista e publicava o jornal "Der Stürmer" ("o atacante"), que foi importante instrumento da propaganda nazista (N.T.)
}

Latitude, Vol. 1, no2, pp.07-46, 2007. 
adaptação (não sendo, portanto, monstros), inexiste qualquer esclarecimento psicopatológico para o fato de terem sido altos funcionários de um regime criminoso.

A Psicologia de orientação psicanalítica e a Psicologia Social elegeram caminhos mais complexos para refletir sobre o Nacional-Socialismo e para apresentar seus resultados. Neste sentido utilizaram de modo crescente as escalas de autoritarismo (Autoritarismus-Skalen) embasadas na famosa escala fascista (Faschismus-Skala) desenvolvida na obra Authoritarian Personality produzida pelo Instituto de Pesquisa Social em 1950. Apesar da ênfase na quantificação, elas adquiriram relativa capacidade explicativa (KINDERVATER; RIPPL; SEIPEL, 2000), porém não na forma concebida pela teoria do caráter autoritário, como específica estrutura da personalidade. Hoje essas escalas sobre o autoritarismo e anti-semitismo têm capacidade explicitativa exatamente se forem utilizadas em comparações internacionais. Se pessoas, em diferentes contextos nacionais, forem testadas sobre ítens específicos relacionados às suas situações históricas e culturais, demonstram-se sempre diferenças mensuráveis entre subalternidade diante da autoridade (Autoritaetshoerigkeit) e autonomia no processo de reflexão, principalmente em relação à autoridade estatal. ${ }^{8}$ Em todos os países existe sempre um solo fértil para reações autoritárias diante de minorias étnicas e religiosas e diante dos socialmente "fracos". Este é um dos núcleos centrais da obra Authoritarian Personality, ou seja, a desqualificação de tudo o que é fraco e o reconhecimento do poder, que redunda numa síndrome autoritária. Rememorando a Psicologia Social de Erich Fromm em sua obra Autoridade e Família (Autorität und Familie), entende-se que alí tratava-se de uma estrutura de caráter sadomasoquista do tipo que se submete para ascender (nach oben buckelt) e dá "coices" para baixo (nach unten tritt). Um elemento marcante dessa estrutura psíquica é a latente homossexualidade que convive com uma forte rejeição da mesma (FROMM, 1936). Nos estudos empíricos do Instituto de Pesquisa Social do período 1929-32 quase não aparece, curiosamente, o anti-semitismo; preconceitos contra os judeus foram tematizados somente na obra Authoritarian Personality, naturalmente em decorrência das experiências políticas de além-mar. Mas os pesquisadores imaginaram ter encontrado além-mar exatamente a mesma estrutura psíquica.

O psicanalista (KAMINER,1997) vincula-se hoje a essa perspectiva psicanalítica quando fala de "obediência incondicional até a morte" ("Kadavergehorsam") característica dos chamados perpetradores diretos ("Direkttäter") do holocausto. Também (BÖLLINGER, 2006) vincula-se a esta perspectiva ao se referir à externalização projetiva de sentimentos de culpa - um mecanismo de autopreservação

\footnotetext{
${ }^{7}$ Assim se manifestou, por exemplo, Göring em 1946, diante do psiquiatra Goldensohn. Cf. Goldensohn 2005, p. 159 e seguintes.

${ }^{8}$ Cf. Feldman 2003, pp. 41-76 e Altemeyer 1981; Id., 1998, pp. 47-92, que definiram autoritarismo como covariação unidimensional de convencionalismo, subalternidade autoritária e agressão autoritária; Cf. também Duckitt/ Fisher 2003, p. 212; Lederer/ Schmidt 1995 e Oesterreich, 1993.
}

Latitude, Vol. 1, no2, pp.07-46, 2007. 
psíquica (Selbstentlastungsmechanismus) igualmente descrito em Authoritarian Personality. Porém Böllinger corrobora a virada antropológica da Psicologia Social do genocídio, principalmente a norte-americana, cujo objetivo consiste na identificação e no desenvolvimento de modelos generalizáveis de ação e reação que poderiam induzir ao genocídio. Em aspectos não insignificantes esses modelos foram extrapolados, em virtude de determinadas situações históricas durante o genocídio no NacionalSocialismo.

$\mathrm{Na}$ interpretação que aqui se defende o autoritarismo descreve um elemento constituinte da cultura alemã, ou seja, é um equipamento mental (mentale Innenausstattung) bastante disseminado e que não se dissolveu com a queda do Nacional-Socialismo. Mecanismos de socialização autoritária na educação de crianças e nas concepções sociais dominantes (gesellschaftliche Leitvorstellungen) mantiveram-se de modo contínuo até os anos 1960 (MEULEMANN, 1985; SCHÜTZE, 1986) e somente foram colocados em questão através do movimento estudantil anti-autoritário, em 1968. Esta mudança somente produziu amplos efeitos em meados dos anos 1970. Aqueles indivíduos que se tornaram agentes do Nacional-Socialismo não se diferenciavam, em relação à socialização infantil, em nada daqueles da geração pós-holocausto. Isto significa que a capacidade explicativa das teses sobre o autoritarismo é idêntica a zero. Entretanto, elementos do autoritarismo na tradição e cultura alemãs desempenham um papel importante para o fato de estas pessoas terem se transformado em perpetradores. Esses elementos revelam a rigidez dos papéis masculinos e femininos, para os quais parecia não haver alternativa. Não havia um projeto de vida legítimo para uma mulher ter filhos, não se casar e apesar disso poder fundar uma existência civil (eine buergerliche Existenz gründen); Somente com dificuldades podia uma mulher nos anos 1920 aspirar a pemanecer trabalhadora e ser esposa, mãe e mulher (DOERRY, 2004; GROSSMANN, 1984). A não correspondência entre essas distintas perspectivas de vida foi assumida, por exemplo, por Gretel Adorno, a qual, ainda durante os anos 1960 assim se expressou diante de Regina Becker-Schmidt: ela teria dito, se tivesse mesmo que se casar, que fosse pelo menos com um gênio. ${ }^{9}$ Ela concluiu os estudos de química, era uma empresária de sucesso e ninguém podia ditar regras para ela. Mas ela pensava que se entrasse para o universo existencial de uma mulher casada, deveria em primeiro plano se dedicar ao marido e aos filhos. Esses rígidos papéis funcionavam de modo complementar para os homens, enquanto provedores da família. A dominação tendencial desses "arranjos entre os gêneros" (Geschlechterarrangements) manifestamse em perspectiva internacional. A crise econômica mundial que antecedeu a era keynesiana desencadeou uma estagnação na atividade produtiva da mulher nas economias capitalistas desenvolvidas. Isto é idêntico ao estabelecimento internacional das donas de casa. De fato a atividade produtiva das mulheres tornou-se norma e realidade econômica antes do casamento. Para a fase da vida depois do casamento,

${ }^{9}$ Cf. Regina Becker-Schmidt no documentário Adorno - Der Bürger als Revolutionär (Adorno o cidadão como revolucionário), Arte, 8.8.2003.

Latitude, Vol. 1, no2, pp.07-46, 2007. 
porém, tornaram-se os ideários da dona de casa e da dependência econômica objetivos perseguidos por mulheres de todas as classes (KRAMER, 1986). Especificamente alemão nesse desenvolvimento era tão somente a concepção da masculinidade complementar. Como demonstrou George L. Mosse (1997), a única concepção de masculinidade na Alemanha era a concepção de masculinidade militarizada. O homem deveria ser duro, ou seja, ter autodisciplina, e é isto o que foi determinante entre os agentes da SS: serem duros contra outrem. Isto é tematizado na exposição de um antigo colega de classe do médico da SS Eduard Wirths, o qual, oriundo de uma resistência política católica, abandonou os estudos de direito em 1933 e se tornou jesuita:

"O Eduard era entre nós o mais generoso, o maior coração mole e o mais capaz de compaixão. E aí ele, especialmente impressionado com o espírito daquela época, não percebeu isso como um valor em si, pois ele acreditava que precisava lutar contra isso: contra a riqueza do sentimento e contra a singeleza de seu coração [...] isso estava naquela época no ar, um homem precisa ser decididamente duro, masculinamente decidido' - o mais era: sentimentalidade."

Seja acrescentado: "[..] Nenhuma relação entre o amigável jovem e o agente da SS" no qual se transformou Eduard Wirths mais tarde; O antigo colega de Wirths só pode imaginar que ele agiu "por puro oportunismo" (ORTHEL; FELS, 1975, p. 20). Também mais tarde Wirths foi classificado como "um molengo" ("Weichling"), tanto pelo comandante de seu regimento na Finlândia como no front oriental, assim como pelo comandante Höß em Auschwitz. Que Wirths tenha tido dificuldade em corresponder a esta concepção de dureza masculina, isso se manifesta no apelido que ele ganhou de alguns prisioneiros para funções medicinais (medizinische Funktionshaeftlinge) em Auschwitz: "Dr. Insangüinário" ("Dr. Unblutig") (LANGBEIN, 1995; LIFTON, 1988; Cf. também OEVERMANN, 2000, principalmente p. 26-30). Em virtude de sua carreira como médico local (Standortarzt) da SS, somos levados a concluir que Wirths procurou compensar sua "falta de masculinidade" comprovando, em Auschwitz, extraordinária dureza. A formação enquanto "homem certo" ("richtiger Mann") deve ter convergido com o papel de consciente provedor e protetor de família e isto foi alcançado muito cedo por todos os médicos da SS. Todos eram casados, muitos tinham mulher e filhos em Auschwitz, como é o caso do próprio Wirths. É Curioso que Franz Lucas tenha sido colocado sob a suspeita, por Wirths, de ser homossexual, já que era o único médico não casado em Auschwitz. Depreende-se daí, pois, que a capacidade para o casamento era um critério para a demonstração da masculinidade e orientação corretas (FREVERT, 1991). Esta fixação em uma masculinidade concebida como dura - para não dizer sadista - e a construção de uma concepção de feminilidade

Latitude, Vol. 1, no2, pp.07-46, 2007. 
complementar desempenham um papel relevante nas concepções de vida dos agentes do holocausto. ${ }^{10}$

Um outro elemento do autoritarismo corresponde ao que Shulamit Volkov (2000) descreveu como o código anti-semita da burguesia na Alemanha. O código antisemita era vigente durante o Império e a República de Weimar e foi transplantado para o Nacional-Socialismo como mecanismo institucional de exclusão. No código cultural da burguesia o anti-semitismo e o ódio contra os judeus não precisavam sequer ser tematizados, pois se se aspirasse a pertencer à grande burguesia e às demais camadas burguesas, a posição anti-semita já era um requisito e uma conotação. O código antisemita era étnico e não religiosamente definido, uma vez que se imaginava reconhecer os judeus já pelo nome. ${ }^{11}$ Que não se interagisse com judeus e com os mesmos não se desejasse contato ou, quando se tinha contato, só de forma cerimoniosa e distante e, ainda assim, somente quando se tinha com eles negócio (Cf. BRUHNS, S., 2003), isso não precisava ser tematizado, pois era silenciosamente válido; este era um padrão convencional, seguido sem solicitação quando se pertencia à "boa sociedade". Daí resulta o que Mommsen (2006) chama de "indiferença moral" da burguesia alemã.

Assim se explica por que na primeira parte do estudo empírico sobre o autoritarismo do Instituto de Pesquisa Social nos anos 1929-1932 - cujos resultados provisórios forçaram a migração do próprio Instituto no mesmo ano -, o anti-semitismo como tal não aparece tematizado. Mesmo nas revistas e nas campanhas eleitorais do NSDAP do final de 1920 até o início dos anos 1930 o anti-semitismo não aparece em relevo como tema político (NEIDHARDT; ANHEIER; VORTKAMP, 1998; WINKLER, 1997, p. 358; MOMMSEN, 1983 e 2002). Porém no Programa do NSDAP e na imaginação de Hitler ele estava sempre presente. No estudo do Instituto de Pesquisa Social quase ninguém se apresentava, entre os que tinham orientação de extrema direita, como anti-semita, mas o anti-semitismo estava sempre implícito: entre os entrevistados encontravam-se alguns Cristãos Alemães. Eles informaram serem Cristãos enquanto confissão e não expressaram de modo algum argumentos anti-semitas; sequer fizeram qualquer referência aos judeus. Mas os Cristãos Alemães, que detinham um quarto dos assentos no Sínodo da Alemanha do Norte, votaram, por maioria, já em 1932, pelo "parágrafo ariano" ("Arierparagraphen"), segundo o qual protestantes de origem judaica estavam impedidos de se tornarem membros. Isto quer dizer que já se havia constituído um movimento protestante anti-semita antes de 1933 e este antisemitismo já tinha se transformado em algo relativamente disseminado como

\footnotetext{
${ }^{10} \mathrm{Na}$ Alemanha nazista havia só uma exceção para o lider carismático Hitler, que queria ser "casado com a Alemanha".

11 Assim Magda Goebbels precisou, em 1920, antes do primeiro casamento com o grande industrial Quandt, mudar o nome judeu provindo de seu padastro Friedländer, que a havia adotado, para o nome não judeu de seu pai biológico, para poder casar-se numa família protestante de classe alta.
}

Latitude, Vol. 1, no2, pp.07-46, 2007. 
mecanismo de exclusão. Após o NSDAP assumir o poder, este mecanismo precisou somente ser alçado ao plano estatal e os Cristãos Alemães, indiferentemente de serem nazistas ou de pertencerem a outro grupo radical de direita, puderam se sentir confirmados, sem esforço, na política anti-semita que iniciaram. Suas demandas foram concretizadas e ao mesmo tempo superadas com medidas legais rigidamente antisemitas (KAMPLING, R., 2006, p. 243-252; SANDER, S., 2003; ÄRZTE UNTER DEM HAKENKREUZ, 2003).

Na República de Weimar:

"mais ainda do que no Império, a burguesia ilustrada e os estudantes (...) constituiam a vanguarda social do anti-semitismo. À ascensão social dos judeus correspondeu a ascensão do anti-semitismo. $O$ principal motivo do anti-semitismo acadêmico, que se infiltrava atraves da ideologia e da cultura, provocava a rejeição de judeus em virtude da concorrência no setor" (WINKLER, 1997, p. 358).

Esta adequada descrição de Winkler não esclarece, porém, por que justamente entre os acadêmicos - à exceção de teólogos, entre os quais a religião se colocava no centro do interesse -, principalmente médicos, juristas e professores, os judeus alemães não foram entendidos como uma minoria religiosa e a rejeição de judeus acadêmicos por acadêmicos protestantes e católicos nunca tomou a forma do conflito (ademais em menor proporção) permanente entre protestantes e católicos até os anos 1960. Deve-se considerar, assim, que o anti-semitismo da burguesia ilustrada já estava definido de modo étnico e nacional-populista (voelkisch) ${ }^{12}$. Uma vez que os judeus alemães, ainda no período do Império, estavam submetidos a uma explícita discriminação, não perderam a visibiliddade social e apareciam no setor acadêmico, após a democratização iniciada em 1918, como bem sucedidos concorrentes.

Burrin distingue entre uma visão de mundo maniqueísta entre os anti-semitas, que caracterizava o anti-semitismo burguês "normal" do século XX nos países do ocidente europeu, e uma visão de mundo apocalíptica que se manifestou principalmente na obra Mein Kampf, de Hitler, e preponderou até o início da segunda Guerra Mundial, na forma da profecia (BURRIN, 2004, p. 68). Pensamentos maniqueístas descrevem personalidades autoritárias. Elementos fundamentais do caráter autoritário que caracterizam um super-ego pouco integrado ou manobrado de fora e que redundam em um ego fragilizado, são prolematizados em Authoritarian Personality:

12 Aqui evitamos traduzir "völkisch" por "popular", já que assim não se captaria o sentido "tipicamente alemão" de definir, com o conceito, fronteiras étnicas e nacionais (N.T.).

Latitude, Vol. 1, no2, pp.07-46, 2007. 


\begin{abstract}
"Convencionalismo, submissão autoritária e agressão como elementos de um objetivado super-ego; Anti-Intracepção, estereotipia e pensamento estrutruturado em categorias de poder como mecanismos de defesa contra um ego frágil; destrutividade e cinismo, tendência à projeção e sexualidade alienada, os quais liberam impulsos não realizados do id em aspectos sociais não transformados em tabu" (ADORNO, et al., 1950, p. 228). ${ }^{13}$
\end{abstract}

Horkheimer e Adorno, durante os anos de 1950 e 1960, começaram a falar sobre a tipologia desenvolvida na obra Authoritarian Personality em estreita relação com os agentes do Nacional-Socialismo, e tinham na mira, de um lado, o tipo autoritário clássico (Cf. citação acima) pressuposto na ação da maioria dos subordinados aos comandos ("Befehlsempfaenger") e, de outro, o tipo manipulativo narcísico autoritário, diante do qual pensavam em Goebbels e Himmler. O pensamento maniqueísta caracteriza ambos os grupos, na forma da rígida separação entre o próprio grupo, construído de modo positivo e o grupo minoritário ${ }^{14}$ ou "estranho", construído negativamente.

O esquema de uma luta apocalíptica descrito por Burrin - a propósito de um discurso de Hitler em janeiro de 1939 - entre a "raça ariana" e a "raça judia" é uma fantasia conspiratória sobre o judaísmo que se agravou com a entrada de novos aliados na guerra contra a Alemanha, repercutindo entre aqueles que tinham, já antes do início da guerra, um papel na perseguição, roubo e expulsão dos judeus alemães, como é caso do próprio Hitler. ${ }^{15}$ Este esquema de uma luta apocalíptica parece ter, para os chamados agentes diretos (Direkt-Täter) do holocausto, se transformado numa espécie de legitimação do genocídio. Neste sentido, Münch enuncia em suas conversas com Bruno Schirra a existência de apenas "duas raças realmente inteligentes", a "ariana" e a "judia", entre as quais somente uma poderia ganhar. Em suas inúmeras autorepresentações públicas, Münch referia-se com prazer a uma suposta fundamentação biológico-racial elaborada por Mengele, que indicava a necessidade de uma "solução final" (Endlösung), a partir da qual os judeus do leste constituiriam uma "reserva biológica" para os judeus ocidentais em virtude da existência de maior número proporcional de crianças entre os mesmos - sem esta reserva os judeus ocidentais desapareceriam em algumas gerações. Em várias passagens de suas conversas com

${ }^{13}$ Para a discussão de questões metodológicas Cf. Jaerisch, 1975.

14 Welzer (2005) utiliza também essa diferenciação entre "ingroup" ("grupo de dentro") e "outgroup" ("grupo de fora"), mas precariamente traduzida por "Wir-Gruppe" ("grupo do nós") e "Sie-Gruppe" ("grupo do eles").

${ }^{15}$ Eichmann, que dirigia o setor de emigração judia em Viena e preferia, na ocasião, o "Plano Madagascar", optou pelo esquema apocalíptico depois que a "solução final da questão judia" foi decidida na Conferência de Wannsee, em janeiro de 1942. Cf. Cesarani (2002) 2004, p. 516;. Cf. Também Herbert, 1998.

Latitude, Vol. 1, no2, pp.07-46, 2007. 
Schirra em 1995 e 1996 Münch evidencia ser um forte anti-semita do tipo maniqueísta, que estabelecia diferenças entre os (bons) judeus ocidentais e os (maus) judeus do leste, como o fez, ainda nos anos 1980, por exemplo, o filósofo Gadamer, que passou o período do Terceiro Reich na "emigração interna" (innere Emigration) (GADAMER, 2004). Esta separação entre os judeus europeus ocidentais, judeus alemães - nossos judeus - era altamente usual entre a burguesia alemã de 1920. Mesmo na casa de Adorno, marcada pela secularização, recebeu o seu colega Leo Löwenthal "proibição de entrar" ("Hausverbot") assim que se tornou pública a atividade social do mesmo junto aos emigrantes judeus do leste (Cf. SCHIVELBUSH, 1983). Se interpretarmos o código cultural anti-semita (VOLKOV, 2000) de modo análogo ao Code of the South, que era vigente até o movimento pelos direitos civis dos anos 1950 nos estados do sul dos Estados Unidos como forma de segregação dos negros - então ter-se-ia estabelecido uma separação marcada por especificidades de classe contra os emigrantes judeus do leste mesmo no interior da grande burguesia judia alemã. A separação classista da burguesia judia ocidental ascendente durante a República de Weimar pode mesmo ter fortalecido as posições dos anti-semitas antes do início da dominação do NacionalSocialismo, porém a imigração de judeus do leste contribuiu para uma renovação do judaísmo na Alemanha durante o mesmo período. Estes são elementos do antisemitismo alemão que foram apropriados pelos Nacional-Socialistas. Esse processo ocorreu muito antes do início da eliminação física.

Muitos sobreviventes dos campos de concentração disseram que o que ocorrera seria algo inconcebível; que uma nação civilizada, que criou esta cultura (alemã) não poderia combinar com esses assassinos em massa ("Massenmördertypen") (JAECKEL; ROSH, 1993). Neste sentido, existe a seguinte manifestação de Adorno (1959) ${ }^{16}$, resultante de uma palestra que ele realizou e que no, entanto, não queria tornar pública:

"a eterna sublimação daquilo que chamamos cultura espiritual (Geisteskultur) é paga [...] com elementos da crueza ou da brutalidade no interior da nossa vida social, na interação entre os seres humanos, principalmente nas formas da vida politica. Se é verdade o que a gente ouve freqüentemente, que alguns dos mais terríveis carrascos produzidos pelo Nacional-Socialismo, quando queriam descansar de suas vergonhosas ações não apenas deixavam tocar discos com as sinfonias de Bruckner, mas também as compreendiam muito bem - eu creio que precisamos aprender que essas antinomias existem realmente, que se pode ser ao mesmo tempo um carrasco e compreender uma sinfomia de Bruckner -

\footnotetext{
16 Provavelmente essa manifestação de Adorno é uma interpretação a posteriori da frase "Escrever uma poesia depois de Auschwitz é uma barbárie" (ADORNO, 1955), que provocou enormes controvérsias. Norbert Frei salienta que Adorno teria escrito essa frase em 1949, mas somente tê-la-ia tornado acessível a um público mais amplo alguns anos mais tarde, em 1955, numa edição de bolso. (Cf. FREI, 1992, p. 108).
}

Latitude, Vol. 1, no2, pp.07-46, 2007. 
então isso seria por assim dizer somente a prova extrema daquele momento de neutralização da cultura, de sua cisão como uma esfera específica diante da realidade. " (p. 249).

Adorno afirmou, pois, que não ocorreria uma contradição entre a orientação estética e cultural, inclusive a capacidade de compreender a cultura letrada (Hochkultur) e a participação no genocídio. Como as manifestações de vários sobreviventes demonstram, prinpalmente daqueles que usaram as poesias que bem conheciam para sobreviver psiquicamente (KLÜGER, R., 1993), essa cultura letrada não é propriedade de ninguém e não foi apenas usada pelos agentes da $\mathrm{SS}^{17}$ para se relaxarem, mas também pelos prisioneiros, para fugirem momentaneamente da insuportável realidade de Auschwitz. Obras da cultura letrada constituiam, de acordo com as correspondentes experiências de socialização marcadas pelo viés de classe, uma possibilidade para a elaboração psíquica daquilo que faziam, ou, no caso das vítimas, daquilo que teriam que suportar. ${ }^{18}$

\section{Tipologia histórico-empírica dos agentes do Holocausto}

A seguir refiro-me ao esboço de uma tipologia de Gerhard Paul (PAUL; MALLMANN, 2004; PAUL, 2002), que considerou quase todas as investigações sobre os agentes do Nacional-Socialismo. Pontualmente coloco em relevo a tipologia da personalidade autoritária (ADORNO, 1973). Paul chega às seguintes caracterizações:

1. O tipo de agente determinado pela visão de mundo (Weltanschauungstäter). Corresponde ao que Ulrich Herbert chama, em seu estudo Best (Cf. HERBERT, 2001), de agentes convencidos (Überzeugungstäter). Best pode ser considerado um tipo exemplar dessa categoria, pois ele dispõe de uma visão de mundo consolidada por elementos da Revolução Conservadora (Konservative Revolution), da estruturação da Europa a partir de perspectivas populistas (völkische Gesichtspunkte) com pretensão de lideranças "germano-arianas" e da eficiência da nova objetividade (Sachlichkeit), em cujo centro se encontra a concepção Nacional-Socialista do corpo popular (Volkskörper). Ele representa um "anti-semitismo racional" que se distancia, de um lado, do "antisemitismo do barulho", típico da SA ("Radau Antisemitismus") e, de outro, - e isto é

${ }^{17}$ Porém existem informações dos prisioneiros, segundo os quais Mengele, durante a seleção, assoviava com entusiasmo uma ária de Rigoletto intitulada Ela amava sua vida - o que revela um cinismo elevado à máxima potência, através do qual, com referências extraídas do contexto lúdico da alta cultura, os assassinos faziam referências às suas próprias ações.

${ }^{18}$ Digno de nota, neste sentido, é o fato de tanto Adorno - nascido na Alemanha - como os sobreviventes dos campos de concentração alemães oriundos de vários países europeus, ainda após a Segunda Guerra Mundial, se prenderem à imaginação de uma nação cultural alemã.

Latitude, Vol. 1, no2, pp.07-46, 2007. 
bem mais marcante - do anti-semitismo convencional do código burguês, que rejeita por considerar inconseqüente: exceções não são feitas pelo "anti-semitismo racional" por que ele não deve "tocar sentimentos pessoais", mas se embasar em fundamentos "científicos" da teoria das raças (Cf. HAHN, 2008; MÜLLER-HILL, 1989). Best desempenhava, como estrategista político de pessoal, uma função integrativa (Scharnierfunktion) entre a administração legal, o serviço de segurança e a SS. Ele montou, com a ajuda de sua política ocupacional, o aparato de agentes (Täterapparat) que planejou, organizou e executou mais tarde a eliminação de judeus, de "ciganos" e dos demais corruptores (Schädlinge) do corpo popular (Volkskörper) - como um agente de escrivaninha (Schreibtischtäter). O ministério público de Berlim Ocidental havia preparado nos anos 1970 uma acusação formal contra Best como sendo o terceiro depois de Himmler e Heydrich na SS, a partir da produção de uma relação de causalidade ininterrupta (Cf. SOLF, U., 2006) entre as suas atividades organizatórias e a ação de agentes diretos (Direkttäter) do Holocausto, de tal modo que ele teria sido, em conformidade com os princípios jurídicos da República Federal Alemã, também condenado como agente principal (Haupttäter), se não tivesse podido se esquivar do processo ao argumentar supostos problemas de saúde.

2. Em segundo lugar trata-se do tipo oportunista, ou do "vagão dos nazistas" (Bandwagon-Nazis). A esta categoria pertencem os médicos da SS em Auschwitz Fischer, Lucas, Münch e Wirths. A situação deles durante a crise econômica mundial teve como conseqüência uma inconsistência de status, que experimentaram de modo muito forte: conseguiram com esforço uma ascensão social, esbarrando inicialmente nas barreiras da seleção pelo desempenho fixadas pelo sistema de qualificação alemão, mas alcançando rapidamente acesso a altas posições com a ajuda de suas identificações com o Nacional-Socialismo e com a entrada na organização de elite da SS. Foi colocado sob objeção se estes agentes principais (Haupttäter) do Holocausto teriam alcançado postos tão altos, ou se, pelo contrário, teriam tido somente posições medianas. Objeções foram colocadas, ao se afirmarem que esses perpetradores principais do holocausto - como Eichmann na posição de Sturmbannführer ${ }^{19}$ - teriam alcançado apenas posições medianas na SS. Wirths, por exemplo, tornou-se em 1944 "Sturmbannführer". Mas estas eram altas posições, que nas condições de guerra estavam reservadas somente para bem sucedidos integrantes das frentes de operação. Se levarmos em consideração a idade deles na época - como Wirths, que aos 32 anos tornou-se chefe de setor e médico-chefe de campo de concentração - então se entende que se tratava de uma alta posição, principalmente se levada em consideração a rígida e estável hierarquia do sistema médico alemão.

Se compararmos os "escritos de justificativas" de Wirths com as "memórias autobiográficas" de Rudolf Höß (Cf. BROSZAT, 2004, p. 15), fica evidente que ambos e 19 "Sturmbannführer" era uma patente usual na SS (Schutzstaffel) e correspondia à patente de
major na Wehrmacht. "Schutzstaffel" (SS) pode ser traduzido como "tropa de proteção" (N.T.).

Latitude, Vol. 1, no2, pp.07-46, 2007. 
de forma muito parecida formulam e descrevem com certo ar de lamúria as suas relações com os superiores, sempre com gestos de completa autocomiseração: "Eu fiz, sim, tudo o que eu tinha que fazer". Autocomiseração é usualmente a única forma de compaixão exteriorizada. O que se oculta atrás disso pode ser descrito como puro autoritarismo. Höß descreve Wirths como um "molengo" ("Weichling"), em quem ele sempre precisava dar um empurrão. Ele se autocomisera por ter que colocar a máscara da força, já que era observado pelo pessoal a ele subordinado, da SS. Se eles tivessem percebido qualquer hesitação, então teriam provavelmente fracassado no encargo de matar.

3. Seja citado também o Perpetrador Excessivo (Exzess-Täter). Paul refere-se aqui ao exemplo do Dr. Dirlewanger ${ }^{20}$. O médico sargento (Sanitätsdienstgrad - SDG) Klehr, que foi condenado no primeiro processo de Auschwitz em Franfurt, seria um outro exemplo desse tipo de perpetrador, que Eugen $\operatorname{Kogon}^{21}$, por assim dizer, considerou como único alvo. Entre os médicos da SS de Auschwitz pode-se citar como participantes desse tipo Entress e talvez Mengele. Abraham Ashkenasi comentou em seu artigo Nazismus und Neonazismus que em toda sociedade, até certo ponto, existem tipos semelhantes de criminosos e assassinos (ASHKENASI, 2000). Significa dizer que tais sádicos e "carniceiros" que se deparam com uma estrutura social favorável, estariam propensos a dar vazão a esses impulsos. Eles constituiriam entre um e cinco porcento da população. Essa constatação significaria que no Nacional-Socialismo entre 1 a $5 \%$ da população teria se tornado ativa e se colocado a serviço do Estado.

4. O quarto tipo é o "matador burocrático" (bürokratische Killer), o perpetrador de escrivaninha (Schreibtisch-Täter). Exemplos desse tipo foram acima citados. Como protótipo do perpetrador de escrivaninha pode-se citar, desde o processo de Jerusalém (1961), Adolf Eichmann. Durante os anos 70 a discussão sobre os perpetradores do Nacional-Socialismo reduziu-se curiosamente aos perpetradores de escrivaninha, os quais teriam recebido comandos de uma central estatal criminosa (Hitler) e os repassado, de suas escrivaninhas, a instâncias subordinadas. Como instâncias subordinadas - meros receptáculos de comandos - sejam citados os guardas do campo de concentração Majdanek, os quais foram parcialmente levados à justiça em

${ }^{20}$ Com a criação do notório batalhão de punições (Strafbataillon) Dirlewanger, o "velho combatente", que teve de renunciar às suas funções oficiais por ter abusado de uma garota de 14 anos, filha de um funcionário do NSDAP, conseguiu dar sua contribuição a Himmler para a "vitória final" do Nacional-Socialismo. Com esse batalhão, para o qual eram recrutados homens selvagens e ladrões, Direlwanger adentrou a Polônia ocupada, roubando, saqueando, estuprando e matando. Mais tarde alemães "arianos" e os ciganos Sinti que serviram durante a Primeira Guerra, bem como prisioneiros de campos de concentração, foram integrados no batalhão e sem qualquer treinamento militar, jogados no front.

${ }^{21}$ Eugen Kogon referia-se aos típicos membros da SS como "profissionais criminosos"; ele próprio ficou durante seis anos recluso como preso político no campo de concentração Buchenwald e já em 1946 elaborou uma análise fundamental da SS nos campos de concentração.

Latitude, Vol. 1, no2, pp.07-46, 2007. 
Düsseldorf. Para estes utilizaríamos hoje a terminologia de perpetradores diretos (DirektTäter/innen). Esta perspectiva sugere que indiretamente muitos outros aparelhos tomaram parte nos crimes e não somente os usualmente conhecidos.

5. Como quinto tipo Paul considera uma mistura entre matadores burocráticos (bürokratische Killer), perpetradores diretos (Direkt-Täter), idealizadores da destruição (Vordenker der Vernichtung) e carrascos (Henker). Com esse tipo fracassa a tentativa tipológica de Paul, por assim dizer, pois uma categoria residual, que contém um pouco de tudo, borra as fronteiras entre as categorias descritas. Gerhard Paul iniciou, porém, a investigação das formas de resistência, principalmente de modo cronológico, do início do "Terceiro Império" ("Drittes Reich") até o holocausto, considerando que não se podia fixar o debate num conceito moral imóvel, a partir do qual tudo se deixaria medir. Talvez dever-se-ia investigar quando e quais formas de resistência poderiam ter tido chances produtivas (PAUL, 2004).

Nesse esquema precisaria Albert Speer - arquiteto e amigo pessoal do "Führer", Ministro da guerra e da produção armamentista, chefe do exército de trabalho "Organisation Todt", um dos mais importantes protagonistas do "Terceiro Reich" (BENZ, 2006) -, cuja auto-estilização como apolítico tecnocrata que nada sabia sobre os crimes do Nacional-Socialismo e que dominou o debate com o passado NacionalSocialista na Repúbnlica Federal Alemã até os anos 1990 (Cf. BENZ in KRAMER, 2006, p. 15 et seq.), ser reclassificado: pois Speer era também um agente determinado pela visão de mundo ("Weltanschauungstäter") - uma observação leiga deixa entrever as lanternas projetadas por Speer no eixo Leste-Oeste de Berlim como uma monumental "nova objetividade" ("Neue Sachlichkeit"), mas na verdade cada detalhe representa um simbolismo "germânico" ou "neopagão" ("neuheidnisch") (Cf. HERDING, 1975). Speer foi um "Perpetrador de escrivaninha" ("Schreibtischtäter") no processo de "desjudificação" ("Entjudung") de apartamentos berlinenses que foram transformados em guetos para a construção do eixo Leste-Oeste, em 1940, sendo que seus ocupantes foram colocados nas primeiras listas de deportação para o Leste em 1941 (WILLEMS, 2002). Em 1942/1943 Speer foi então co-organizador do holocausto, já que ele comprovadamente autrorizou os planos de construção de novos crematórios em Auschwitz (Cf. BENZ, 2006). Contrariamente às suas manifestações públicas diante do Tribunal de Nuremberg, assim como às suas publicações autobiográficas após cumprir pena de 20 anos na prisão de criminosos de guerra de Spandau, ele apenas fingiu ter uma consciência da injustiça ("Unrechtsbewusstsein") cometida e isso ilumina o fato de ele ter, de 1971 até a sua morte em 1981, leiloado obras de arte roubadas de Judeus no valor de um mihão de Marcos (ALY, 2010). Seu ilimitado oportunismo o caracterizou até a morte.

Latitude, Vol. 1, no2, pp.07-46, 2007. 


\section{A latência comunicativa do anti-semitismo: dificuldades de reconstrução dos motivos dos perpetradores}

O mais difícil é investigar o anti-semitismo contemporâneo dos perpetradores e suas transformações (Cf. MOMMSEN, 2004, p. 16), exatamente por que o antisemitismo, nas esferas públicas dos Estados pós-holocausto, deve ser mantido comunicativamente em estado de latência (Cf. HOLZ, 2001, cap. VIII; Cf. BENZ, 2004). Mesmo aqueles comandantes de campos de concentração que aguardavam processos militares, segundo resultados da investigação de Karin Orth, aproveitavam-se desses tabus, antecipadamente, para salvar as próprias cabeças. Mesmo imediatamente após o fim da Segunda Guerra não teria sido, por isso, mais fácil investigar as motivações do anti-semitismo. Fahrenberg e Steiner (2000) acusam o Instituto para a Pesquisa Social (Institut für Sozialforschung) por não terem realizado nenhuma investigação empírica sobre os perpetradores do Nacional-Socialismo - num contexto repleto de perpetradores (não processados e não punidos) (KLEE, 1992 e 2003). Correto é dizer apenas que perpetradores do Nacional-Socialismo, como tais, não foram objetos de estudos empíricos. Que perpetradores do Nacional-Socialismo teriam personalidades autoritárias ou sadomasoquistas, que tivessem perturbações narcísicas ou fossem do tipo "psicótico" e "manupulativo", a isso referiram-se frequentemente Adorno e Horkheimer em publicações durante os anos 50 e 60. Quase ninguém se ocupou de modo tão intenso na esfera pública sobre os efeitos do Nacional-Socialismo na República Federal Alemã, como Adorno (1970). O diagnóstico da atual sociedade industrial esteve no centro das investigações empíricas do Instituto. Que nesta sociedade viviam velhos nazistas, isso era conhecido - não necessitava ser comprovado.

Fahrenberg e Steiner aplicaram, eles próprios, em 1963, questionários entre antigos membros da SS que contataram através de um ex-General da SS. Deve-se notar, para sermos cientificamente honestos, que o material não é representativo para a totalidade da SS ou para um grupo específico dentro da SS, pois faltam completamente informações sobre origem e contexto, e até mesmo sobre as unidades onde os homens da SS - voluntariamente ou sob coação? - prestaram seus serviços, o status que ocuparam e sobre as mortes das quais participaram ou não. A intenção dos autores é encontrar explicações sobre a relação entre autoritarismo e pertencimento à SS. Por esta razão, eles comparam ex-membros da SS com antigos membros da "força de defesa" (Wehrmacht). Plausível é o resultado, segundo o qual ex-membros da SS elegiam com mais frequência do que membros da Wehrmacht "honra" e "lealdade" ao invés de "justiça" como valores importantes. Saliente-se o ditado propagado por Himmler: "Sua honra seja lealdade". Fascinante é que eles, ainda em 1963, mantinham-se firmes na afirmativa, e provavelmente com razão, de que a maior parte dos investigados estavam entre os nacional-socialistas incorrigíveis. Menos surpreendente é, por outro lado, o fato de ex-membros da SS não terem eleito Jerusalem e Moscou entre as dez cidades onde

Latitude, Vol. 1, no2, pp.07-46, 2007. 
mais gostariam de viver. Porém de onde retiram os autores a constatação de que seus entrevistados não foram influenciados pelo processo contra Adolf Eichmann ocorrido em Jerusalem entre os anos 1961 e 1962 e por que não colocaram nenhuma questão em seus questionários sobre suas percepções sobre o processo? Os meios de comunicação noticiaram detalhadamente sobre o processo. Tal afirmação poderia somente ser feita se a gente estivesse exatamente informado sobre o fato de que os ex-membros da SS liam exclusivamente os jornais tradicionais da SS, que se silenciaram completamente sobre o processo no ano anterior ao questionário? Parece ocorrer aqui algo semelhante ao ocorrido com psicólogos, que tiveram a oportunidade de entrevistar prisioneiros famosos do primeiro processo de Nuremberg. Esses autores publicaram suas pesquisas somente em 1970, quando não ocorria mais um debate público sobre os perpetradores do Nacional-Socialismo contra judeus, ciganos Sinti e Roma e reclusos da psiquiatria. Os autores provocaram pouca ressonância às suas investigações. Corretamente eles perguntam por que tão poucos membros do Partido Nacional-Socialista e membros da SS foram investigados enquanto ainda era possível, e por que a reflexão sobre eles, que se tornaram reconhecidos membros da sociedade democrática do pós-guerra, não foi desenvolvida pelas ciências sociais. Porém tais perguntas não são adequadas, se considerado o caráter meramente quantitativo da investigação de Fahrenberg e Steiner. De que adianta contrapor membros da SS em geral a membros da "força de defesa" (Wehrmacht) em geral? Nós sabemos que além de batalhões policiais (Polizeibataillone) $^{22}$ também os soldados da Wehrmacht estacionados no "Ostfront" oficialmente receberam ordens e participaram do massacre contra a população judia. Isso foi mais uma vez constatado ao final da primeira exposição da Wehrmacht no Instituto de Pesquisa Social de Hamburgo:

\begin{abstract}
"sobre o argumento (em circulação na exposição da Wehrmacht, ASB) principal, de que o genocídio contra judeus não permite falar de uma Wehrmacht "limpa", não há o que interpretar. Esse fato não será negado, aliás, por nenhum historiador serio, não importa de qual tendência ou orientação política. Um novo debate entre historiadores (Historikerstreit) não teria legitimidade em virtude dessa relativa unanimidade" (MEDICUS, 1999, p. 8).
\end{abstract}

Por outro lado, também não eram todos os membros da SS e muito menos todos os guardas dos campos de concentração convictos e zelosos assassinos.

Em princípio os autores levantam a questão de saber por que a Escola de Frankfurt falhou em investigar os perpetradores do holocausto na República Federal

${ }^{22}$ Segundo Curilla (2006, p. 941) entre os anos de 1941 e 1944, no báltico e na Rússia Branca, "mais de 20.000 soldados alemães executaram comandos criminosos". Cf. Também Klemp (2005).

Latitude, Vol. 1, no2, pp.07-46, 2007. 
Alemã. Nos últimos grandes estudos empíricos do Instituto para a Pesquisa Social dos anos 50 foram feitas tentativas de utilização da Escala F (F-Skala) em grupos focais. Tais experimentos grupais têm sido grosseiramente subestimados em sua força explicativa. O silêncio de $60 \%$ dos participantes das discussões em grupo foi interpretado por Fahrenberg/Steiner como expressão do sentimento de culpa de velhos nazistas ou como prova da ineficácia do procedimento. O silêncio é, em princípio, ambíguo. Sempre existem em grupos focais pessoas que não falam e pode também existir silêncios relacionados à situação ou à estrutura da personalidade e que, portanto, nem de longe evidenciam a existência de sentimento de culpa de velhos nazistas. O capítulo escrito por Adorno "Schuld und Abwehr" ("culpa e defesa") para a obra Gruppenexperiment (Experimentos Grupais) (POLLOCK, 1955, p.381-426) contém, contrariamente, no tópico "Reações nazistas", uma análise detalhada da questão "Culpa, Judeus, Ocidente e Democracia" (Id., p. 238) a propósito das posições manifestas pelos participantes, que se distanciam bastante do tópico "Síndrome do autoritarismo" da obra Authoritarian Personality. Os temas lançados como estímulo para a conversação nas discussões grupais colocavam em relevo a eliminação dos judeus europeus ("culpa") e um antisemitismo, cuja função reside na defesa contra sentimentos de culpa, assim como na identificação com os valores da nova democracia ocidental e suas defesas contra o antiamericanismo. A simples contraposição entre tipos de caráter "positivos" e "negativos", que poderia levar a resultados através de procedimentos exclusivamente quantitativos, evitaram os autores de Gruppenexperiment (POLLOCK, 1955), na medida em que levaram em consideração as ambiguidades e ambivalências de manifestações linguísticas isoladas de seus contextos. Neste sentido, eles não interpretaram verbalizações filosemitas pura e simplesmente como manifestações de nãoantisemitismo entre o grupo investigado. Pelo contrário, eles as utilizaram como categorias descritivas e, com razão, pois posições filosemitas podem ocultar, através de projeções psicológicas, exatamente a existência do ódio contra judeus. O problema da não-comunicabilidade do antisemitismo após o holocausto estrutura também as situações de interação nas entrevistas realizadas com os perpetradores e agentes do Nacional-Socialismo.

\section{Médicos da SS e outros atores}

Fischer, Wirths, Münch e Lucas não são "velhos batalhadores" do NSDAP, mas foram, antes de 1933, membros de organizações radicais de direita que representavam visões de mundo radicalmente anti-semitas e excluiam judeus de suas atividades. Isto quer dizer concretamente: todos esses médicos da SS em Auschwitz tiveram experiências de socialização política já antes de 1933 como membros de organizações

Latitude, Vol. 1, no2, pp.07-46, 2007. 
radicais de direita ou de atividades estudantís, nas quais agitadores nacionais populistas alemães tinham relevo.

Após 1933 os membros do NSDAP Fischer e Wirths não queriam expressamente pertencer ao quadro dos "Radau-Antisemitas" (da SA) ${ }^{23}$. Para Fischer, no entanto, era desejável, durante os estudos de medicina, não ter concorrentes judeus (Cf. DIRKS, 2006). Münch mantinha-se firme, ainda nos anos 1996 e 1997, na posição de que o predomínio judeu no campo da medicina deveria ser superado.

Em seus escritos de justificativa Wirths escreve que a sua casa paterna não era anti-semita, razão pela qual teria continuado a tratar pacientes judeus, ainda depois da vigência da lei racial de Nuremberg (Cf. BEISCHL, 2005, p. 29). No entanto Wirths, em seus escritos dirigidos a Himmler em 1936, apresentou-se e, provavalmente de modo inconsciente, como representante de uma das mais perigosas variantes do antisemitismo racialista ${ }^{24}$, recomendando-se e a sua noiva ao líder da SS como um casal ariano modelo.

Münch descreveu sempre ter visto, imediatamente após chegar a Auschwitz, seu colega de classe judeu, Oppenheimer, entre os detentos; No entanto, teria sido advertido por colegas da SS da impossibilidade de procurar contato com o antigo colega em virtude da rígida proibição vigente em Auschwitz de confraternização, especialmente com detentos judeus. Münch se representa como salvador impedido diante de seu colega de classe judeu-alemão. Fischer, Münch, Wirths e Mengele puderam receber contribuições no campo da medicina de "capacidades" judias ou deixavam que trabalhassem para si; Münch se utilizava também de "capacidades" sexuais de detentas submetidas a seu controle, sem alardear isso diante da SS. Embora tenha sido Wirths o primeiro médico local de Auschwitz a criar a possibilidade para que médicos judeus tratassem outros detentos judeus, construiu simultaneamente um sistema de segregação entre detentos judeus e não-judeus: para Wirths o contato físico necessário entre médico e paciente excluia categoricamente tratamentos que ultrapassassem as fronteiras "raciais". Possíveis refinamentos no anti-semitismo dos médicos da SS são absolutamente desinteressantes na situação de Auschwitz, por que eram todos tão antisemitas que, mesmo contra a vontade, tomavam parte na "seleção da rampa" (Rampenselektionen) ${ }^{25}$. Que Wirths retomava o seu trabalho na rampa quando

23 Este tipo de anti-semitismo pode ser considerado um dos tipos mais "vulgares" de antisemitismo e se desenvolveu entre a pequena bueguesia alemã desde 1870. Ele deu origem a vários partidos anti-semitas e colocava a culpa nos judeus por todos os males econômicos (N.T.)

${ }^{24}$ Koonz (2003) demonstrou que o anti-semitismo supostamente fundamentado cientificamente foi responsável pelo desenvolvimento do "cold pogrom" (M. Horkheimer) no NacionalSocialismo.

${ }^{25}$ Quando os trens chegavam a Auschwitz os detentos eram obrigados a se alinharem numa rampa, em duas fileiras: mulheres e crianças de um lado, os homens de outro. Os médicos definiam, com um olhar superficial, quem era capaz de trabalhar e quem não era. Quem era

Latitude, Vol. 1, n², pp.07-46, 2007. 
não o podia realizar em virtude de outros compromissos (Cf. LANGBEIN, 1995), isso demonstra que ele entendia essa atividade como dever militar diante da SS, através da qual o oficial comandante demonstrava aos subordinados, com "bom exemplo", que era capaz de se desligar de sentimentos pessoais. Mengele constitui, neste sentido, uma exceção, pois tomava parte com prazer nesse tipo de atividade e ao mesmo tempo coletava material humano para a sua pesquisa genética e assim podia dar continuidade à carreira acadêmica no Instituto Kaiser-Wilhelm de Berlim. Nenhum deles pode ser classificado como precursores da destruição (Vordenker der Vernichtung) ou como perpetradores de escrivaninha (Schreibtischtäter). De simples oportunistas em um contexto acadêmico e profissional fortemente anti-semita eles se tornaram perpetradores diretos (Direkt-Täter) do holocausto, ou seja, em técnicos do genocídio racionalizado.

A concepção do clássico caráter autoritário deixa-se aqui ilustrar a propósito da descrição de Höß em seus relatos sobre a visita de Himmler à Auschwitz em 17 de julho de 1942 (BROSZAT, 2004). Höß se caracteriza, como Eichmann e outros o fizeram diante da justiça, como um soldado subordinado e obediente. No entanto fica claro no relato que ele escreveu quatro anos e meio após a visita de Himmler que ele se colocava diante do mesmo num tipo de relação autoritária de dependência que extrapola uma relação normal entre subordinados e superiores. Höß tentava ler os pensamentos na expressão de Himmler, alternadamente o admirava ou se sentia negligenciado. Ele registra se sentir amedrontado quando Himmler, ao visitar os barracões dos doentes, puxava o canto da boca para baixo e se silenciava. Ele era dependente do consenso de Himmler, ficava agradecido e se sentia aliviado quando Himmler perguntava-o finalmente pela esposa - então tudo ficava bem de novo.

Demonstra-se, assim, elementos de "fraquezas do ego" (Ich-Schwäche) que caracterizam o tipo autoritário, de acordo com a Personalidade Autoritária (Authoritarian Personality). Em princípio isso não esclarece por que tais estruturas psíquicas são mais disseminadas do que restritas a Höß, Wirths e outros. No entanto, trata-se de condições psicológicas e mentais sem as quais esses agentes não teriam matado. No caso em pauta é relevante que uma tal relação autoritária de dependência - uma relação de subserviência pessoal, como disse Karin Orth - tenha existido entre o comandante de Auschwitz, Höß e o seu mais alto superior Heinrich Himmler (ORTH, 2000). No caso de Wirths essa relação existiu igualmente ainda após a derrota alemã e a morte de Himmler, uma vez que ele se reportava à situação em Auschwitz pelo menos para produzir os rudimentares escritos de justificativa. Relações de subserviência pessoal são estruturas psíquicas típicas da máfia. Isso possibilita a seguinte tese: as estruturas emocionais dos perpetratores diretos do genocídio tinham essa qualidade típica da máfia. Ela se colocava - apesar do juramento a Hitler e Himmler - além da simples adesão à "ordem" da SS, já que ao longo da guerra muito amplamente se recrutou. A

definido como incapaz, não era sequer registrado, mas imediatamente encaminhado para a câmara de gás (N. T.)

Latitude, Vol. 1, no2, pp.07-46, 2007. 
preparação para tais ligações emocionais primitivas transcorria através de rituais e distintivos - como as tatuagens - e a rígida identificação de arianismo, porém construídas elas eram no processo de interações pessoais. Tais relações de subserviência pessoal existiram entre Goebbels, Göring, Speer, Bormann, Himmler, Frank de um lado, e Hitler de outro. Elas existiram entre Heydrich, Pohl, Höß e o conjunto dos comandantes de um lado e Himmler, de outro. O homem central para a expansão organizacional do espaço de poder de Himmler para a esfera administrativa estatal, Dr. Best, terceiro homem do Escritório Central de Segurança do Reich da SS (Reichssicherheitshauptamt - RSHA) estava ligado dessa forma a Himmler e supostamente ainda de modo mais forte a Heydrich, como comprovam suas devotas missivas que tentavam restaurar as velhas relações de confiança (Cf. também HERBERT, 2001). De modo contrário, a Best estavam ligados os jovens juristas por ele recrutados, que dirigiam, no início da guerra, os "grupos de ataques" (Einsatzgruppen) na Polônia e que eram, portanto, perpetradores diretos, e, mais tarde emitiam comandos de morte como perpetradores de escrivaninha no Escritório Central de Segurança do Reich da SS (RSHA) (WILDT, 2002). Nem todos os perpetradores estavam mutuamente ligados por esse tipo de estrutura, mas havia surgido uma grande rede de tais relações de subserviência que possibilitou a existência de relações pessoais de cooperação entre antigos membros da Freikorps, "velhos combatentes", aqueles que tomaram parte na "limpeza intrapartidária" e no assassinato de Röhm e outros em 1934, e esta rede funcionou, mesmo quando a derrota militar foi antevista, até o fim.

Entre os médicos da SS de Auschwitz Fischer estava pessoalmente ligado a Wirths, Münch ao bem sucedido colega de estudos, por ele admirado e seu superior no Instituto de Higiene da SS Bruno Weber e também ao igualmente admirado cientista Mengele, que por sua vez se esforçava para concluir a Livre Docência orientada por Otmar von Verschuer no Instituto Kaiser-Wilhelm e, colocava-se, pois, diante deste numa relação acadêmica de aprendiz. Quando Hans Delmotte não conseguiu realizar seu primeiro "trabalho na rampa", foi recomendado por Wirths a Mengele; Lucas não foi marcado por esse tipo de relação de subserviência, se levarmos em consideração aquilo em que acredita Winfried Meyer, o que não o impediu, aliás, de ter tomado parte no genocídio. $O$ exemplo de Lucas revela que as considerações aqui desenvolvidas retratam o envolvimento de longa duração com a matança ${ }^{26}$.

${ }^{26}$ Karin Orth desistiu de incluir funcionários do setor D („,setor de saúde“) em seus estudos comparados sobre a SS nos campos de concentração, tendo em vista a pequena permanência (dois meses e meio) de médicos em campos de concentração específicos. Nenhum outro segmento de pessoal engajado em campos de concentração teve um nível de flutuação tão alto. A sociologia industrial interpreta essa alta flutuação como sintoma de problemas de identificação com o trabalho. Dever-se-ia supor que os médicos tinham grandes dificuldades de identificação com seu trabalho nos campos de concentração, já que a sua qualificação para o tratamento e para a cura quase não foi usada. Os estudos comparados das biografias individuais dos médicos da SS em Auschwitz confirmam essa suposição. O médico local da SS Wirths ficou quase 27 meses em Auschwitz, seu substituto Fischer 25 meses, Mengele e Münch ficaram 20

Latitude, Vol. 1, no2, pp.07-46, 2007. 
Evidentemente muitos militares da forças armadas alemãs durante o Terceiro Reich (Wehrmacht) participaram dos homicídios, sem terem construído esse tipo específico de ligação (FUNKE, 2000). Mas os ideólogos planejadores, organizadores e executores do holocausto e da eliminação dos "ciganos" foram marcados por esse tipo de relação pessoal de subserviência, que, por sua vez, fortalecia hierarquias e estruturas militares. E ainda válido, neste sentido, o que muitas investigações sobre os crimes do Nacional-Socialismo colocaram em relevo, notadamente que a participação conjunta e a cumplicidade produzem um tipo de "pacto sanguinário" ("Blutkitt") capaz de ligar mesmo perpetradores inimigos entre si após os primeiros homicídios e, ainda de modo mais estreito, após a execução de cada crime. Os médicos da SS em Auschwitz, permaneceram lá após 1942, se comparados a outros médicos em campos de concentração, por um tempo médio muito maior.

Para o médico local Wirths, que apesar do remorso permaneceu tanto tempo em Auschwitz, cabe a observação de que ele mantinha desde cedo esse tipo de relação de subserviência ideológica e acadêmica com o Presidente do Instituto de Higiene Racial do Estado da Turíngia, Prof. Dr. Karl Astel (Cf. BEISCHL, 2006; WEINDLING, 1991) - o "velho senhor" e fundador da associação de extrema direita "Gilde Bergfried" -, de modo que estava convencido de que a esterilização involuntária de arianos e nãoarianos ameaçadores do "corpo social" ("Volkskörper") era mesmo uma intervenção médica necessária, caso contrário não teria assistido as esterilizações. Astel, que já nos anos 1930 defendeu publicamente a eliminação preventiva de criminosos "geneticamente predispostos" antes mesmo de terem praticado crimes, deve ser sem dúvidas caracterizado como um ideólogo da eliminação. Na Turíngia Astel constituia "uma figura de ligação entre a higiene racial acadêmica e a SS [...] consolidando uma notável concentração de poder no setor de saúde pública" (WEINDLING, 1991, p. 95). Ainda que Wirths não tenha compartilhado em detalhe todas as posições de Astel, estava sem dúvida pelo menos convencido da necessidade política de isolar "criminosos" e "inimigos do povo" nos campos de concentração; a prática da violência contra indivíduos definidos como inimigos e ameaçadores ele já considerava legítima antes da Segunda Guerra Mundial. Ao manipular Himmler para a ascensão profissional

meses, Delmotte - possivelmente com interrupções - 9 meses; Lucas, substituto de von Helmersen, que foi remanejado para um batalhão de pára-quedas no front, ficou 8,5 meses em Auschwitz. Os médicos da SS Entreß, Kitt, König e Rhode, aqui não incuídos, já estavam em Auschwitz antes da entrada de Wirths em setembro de 1942 e permaneceram até a desocupação, em 17 e 18 de janeiro de 1945 ou foram, durante o ano de 1944 remanejados para outro campo de concentração. Além do mais, Wirths, segundo a sua própria construção em escritos de justificativa do natal de 1943 (confirmada por Langbein e Lill), permaneceu somente em seu posto, por que teria sido solicitado "penhoradamente por seus prisioneiros". Cf. KRAMER, H. Das 'doppelte Selbst' des SS-Standortarztes von Auschwitz, in: Kramer, H. (ed): NS-Täter aus interdisziplinärer Perspektive. München, 2006, p.197-230 und Kramer: Sammelrezension. U. Völklein: Dr. Eduard Wirths, in: H-Soz-u-Kult (online-Rezensionen) 30.11. 06. URL:http:hsozkult.geschichte.hu-berlin.de/rezensionen/id=8665.

Latitude, Vol. 1, no2, pp.07-46, 2007. 
de Wirths, Astel tanto contribuiu para a constituição de um tipo de relação pessoal de subserviência provavelmente unilateral do segundo para o primeiro, que Wirths em 1945, após o final da guerra, foi capaz de reestruturar seus escritos de justificativa.

\section{Considerações Finais}

Se as relações aqui discutidas levam a pesquisa para a direção certa, então fica evidente que a tentativa de construir um tipo ideal para classificar os perpetradores do Nacional-Socialismo, a partir do material selecionado, não levará a lugar algum. Ela não permite esclarecer por que pessoas normais se transformaram em assassinos no Nacional-Socialismo; por que protegeram e apoiaram assassinos (como as próprias esposas), não se envergonharam de tirar proveito pessoal do genocídio contra judeus ou aceitaram tudo, sem reação visível, como efeito colateral da guerra - aí incluídos os espectadores de ambos os sexos.

Ulrich Herbert rejeita as diferenças políticas entre o espectro da direita da República de Weimar como pista para explicar a conduta dos perpetradores no Nacional-Socialismo (HERBERT, 2004). Membros das elites nunca se decidiram completamente pelo envolvimento ou pelo distanciamento, porém "sentimentos de ambivalência" não os impediram de participar. Não deve ser visto como um caso único o exemplo de ambivalência citado por Ulrich Herbert a propósito do especialista em administração e organizador da eliminação dos judeus em Lemberg, Dr. Losacker, que ousou criticar publicamente a política anti-polonesa do regime Nacional-Socialista (Cf. BERG, 2002, p. 14). O que aqui se identifica como ambivalência emerge, porém, a partir de um olhar mais aprofundado, como orientação minoritária, mas com influência crescente enquanto esquema da política racial ao longo da Segunda Guerra: a idéia de que entre a população eslava existiria uma mistura de elementos "arianos" valiosos (CZARNOWSKI, 2000), permanecendo porém a oposição entre "arianos" e judeus. Tanto Eduard Wirths como a guarda de campo de concentração Johanna Langefeld (Cf. SCHWARTZ, J., 2006) parecem ter seguido esse esquema. Um outro esquema minoritário levou, quando se aproximava o fim da guerra, à reprovação do genocídio contra judeus, mas não impediu o médico da SS Lucas de participar da política de esterilização em massa contra "ciganos" a partir da consideração de que esse grupo era duplamente estigmatizado: não apenas "racialmente", mas por serem "associais". No interior do grupo de ideólogos raciais da SS existia, saliente-se, um forte dissenso entre aqueles que queriam preservar "ciganos racialmente puros", eliminando os "miscigenados", e aqueles que queriam proceder exatamente de modo contrário.

O legado, tão importante agora como antes, da primeira investigação sobre a SS, de Eugen Kogon (1946), produz na atualidade provavelmente efeitos limitadores para a compreensão do fenômeno. A corruptibilidade da SS, também confirmada pelas

Latitude, Vol. 1, no2, pp.07-46, 2007. 
investigações mais recentes, compreende o desenfreado enriquecimento pessoal de membros da SS em Auschwitz - e em outros lugares - a partir do comportamento pontual dos funcionários estatais, como o fez o magistrado da SS em Auschwitz Dr. Konrad Morgen. Neste sentido, finalmente o estudo de Götz Aly (2005) demonstrou que o Estado Nacional-Socialista desenvolveu um processo de lavagem de dinheiro das fortunas subtraídas aos judeus assassinados, através do orçamento público dos países europeus ocupados, antes de tê-las distribuído na Alemanha, ou seja, mesmo no plano estatal já se haviam consolidado estruturas mafiosas e delas participavam de fato funcionários que não tinham noção do caráter criminoso de suas ações. Os acadêmicos da SS viam-se a si próprios como parte da elite alemã, como funcionários, como comprovam por exemplo as renovadas petições, nos anos 1950, de Lina Heydrich, pelo recebimento de aposentadoria por viuvez (DEDERICHS, 2006), mas a confidencialidade ("Omertà") $)^{27}$ com a qual eles executaram seus contratos de morte e as relações de subserviência pessoal que tornaram possível assumí-los demonstra a existência imediata de estruturas mafiosas que lhes permitiam sentirem-se materialmente protegidos. Eles mantiveram a hierarquia social normal de valores: uma vez que matar é um crime "capital" ("Kapitalverbrechen"), então o roubo pode ser visto como um comportamento aceitável; isso confirma o requisito de "compreensão humana saudável" solicitado nos questionários de Himmler aos candidatos à SS e a esse respeito nenhum deles quis se consultar com uma instância de autoridade moral. Esse padrão não pode, no entanto, ser generalizado para todos os perpetradores do Nacional-Socialismo que participaram dos homicídios. Por exemplo, uma enfermeira que tomou parte na "eutanásia" disse, durante o interrogatório, que embora tivesse seguido o comando de morte de seu médico superior jamais teria seguido o comando de roubar algo, pois o roubo seria uma injustiça que contrariaria o que aprendera com sua família de origem (Cf. STEPPE, 1993, p. 114; STEPPE; ULMER, 1999, p. 76; WELZER, 2005a, p. 67) ${ }^{28}$. Aqui o comando emitido pela figura de autoridade - que, alías, era especialista em diferenciar entre "vida digna" ("lebenswert") e "vida indigna" ("lebensunwert") -, parece ter suspendido a orientação normal diante dos valores sociais vigentes.

Gesine Schwan colocou no centro de sua investigação "Política e Culpa" ("Politik und Schuld") a questão da relação entre indivíduos e valores sociais e a discutiu a propósito da tese formulada por Lifton sobre médicos da SS, Stangl, Höß, Speer e outros. Ela assume a tese de Lifton sobre a cisão e a duplicação do "eu“ em um "eu" normal ("normales Selbst") e em um "eu-Auschwitz" ("Auschwitz-Selbst"), enquanto "duplicação da moral" ("Verdoppelung der Moral"): a moral normal e tradicional continuaria existindo e ao mesmo tempo surgiria, para os perpetradores da SS, uma nova, interna moral, como a formulada e incorporada por Himmler. Do mesmo

${ }^{27}$ A expressão omertà originou-se da palavra italiana umiltà (humildade) e é comum em regiões da Itália onde a máfia é poderosa. Pode ser entendida como "voto de silêncio" (N.T.)

${ }^{28}$ Welzer 2005(a), p. 67 cita essas declarações para comprovar que matar, no contexto do Nacional-Socialismo, era percebido como um dever moral e uma ética do trabalho.

Latitude, Vol. 1, no2, pp.07-46, 2007. 
modo que Schwan, também Harald Welzer (2005a, p. 89) fala do surgimento de uma nova moral Nacional-Socialista. Claudia Koonz (2003, cap. 2) ${ }^{29}$ demonstrou contrariamente e de modo convincente que os valores e normas sociais vigentes não foram fundamentalmente reformulados ou substituídos por outros, mas que o universo de representações morais foi reduzido ao próprio grupo étnico, definido como "alemão ariano" - processo este desencadeado pela elite intelectual do radicalismo de direita e do racismo "científico". A homogeneização alavancada por acadêmicos teria redundado na etnicização da consciência e na transformação da consciência dos alemães comuns em consciência nazista ("Nazi-Gewissen").

A intenção de Welzer consiste em responder à questão sócio-psicológica de saber por que eles (os assassinos) realizaram seu trabalho sanguinário com alegria, indiferença ou nojo (WELZER, 2005a, p. 81). Através de uma sincronização inicial do "enobrecimento coletivo" ("kollektive Nobilitierung") que desencadeou um "sentimento de pertença a uma raça de senhores superiores" ("Herrenrassen-Überlegenheitsgefühl") entre a comunidade nacional-popular "ariana" ("arische Volksgemeinschaft") e através da desclassificação simultânea de judeus e judias no Império Alemão ter-se-ia desenvolvido uma "dinamização da exclusão", cuja ausência de limites levou finalmente à eliminação de uns pelos outros. A disposição para matar surge primeiramente no contexto desse dinâmico processo (Id., p. 75). A partir de Browning (2005, p. 66-76) Welzer inverte, na seqüência, a questão: Digno de esclarecimento não seria o fato de terem tantos participado do genocídio, pois "segundo as medidas antigamente estabelecidas os assassinos eram normais e os resistentes, a exceção" (WELZER, 2006, p. 37). Digna de esclarecimento seria, pelo contrário, a questão de saber por que alguns, "espontaneamente" ou de outro modo, encontraram forças para resistir ou para negligenciarem os comandos de morte. Pois entender a eliminação dos judeus e de outros como homicício teria sido uma construção "a posteriori" ("nachträgliche Konstruktion") e que nós, de modo errôneo - e arrogante? - a transportaríamos para uma situação dos perpetradores de antigamente, definida então de modo absolutamente distinto. Esta interpretação de Welzer precisa ser refutada: matar era, depois como antes, um "crime capital" e a confidencialidade prescrita pelo próprio regime leva-nos a refutar tal interpretação. Welzer pensa precisar esclarecer somente a "matança manual" dos grupos de ataque e dos batalhões policiais da SS, por que a eliminação industrial em massa nos campos de concentração não teria sido nada mais do que uma "otimização do processo de matar" para aliviar psiquicamente os perpetradores. Decisiva teria sido a adaptação à pressão grupal emanada da nova identidade coletiva ("neue Wir-Gruppe") dos grupos de ataque da SS e dos batalhões policiais estacionados na Rússia em 1941:

\footnotetext{
${ }^{29}$ Koonz analisou exemplarmente o papel do jurista Carl Schmitt, do filósofo Martin Heidegger e do teólogo protestante Gerhard Kittel.
}

Latitude, Vol. 1, no2, pp.07-46, 2007. 


\begin{abstract}
"Dentro de poucos meses encontramos, pois, uma dramática escalação dos fuzilamentos de judeus, ainda que pequenas ações numericamente inferiores possam ser relatadas já há um ano e meio atrás na Polônia, [...] alcançando quantitativa e qualitativamente uma nova dimensão. " (WELZER, 2005a, p. 155).
\end{abstract}

Para Welzer, é no espaço de tempo registrado a partir do início da guerra contra a União Soviética que ocorre a "profissionalização do trabalho de matar".

Welzer pensa que o matar não estaria, na "instituição total campo de concentração" ("totale Institution Vernichtungslager") - composta, segundo Höß, por "seres em instalações de destruição" ("Menschen-Vernichtungsanlagen") -, relacionado "a um encontro direto entre perpetradores e vítimas". Que este argumento não é correto e que também não tenha sido assim interpretado pelos perpetradores comprovam inúmeras declarações deles mesmos e de prosioneiros sobreviventes. Sejam citados, como exemplo, a descrição de Fischer ${ }^{30}$ sobre o seu trabalho na rampa e o fato de Wirths ter encontrado, uma vez, uma jovem judia-holandesa, a quem, depois de ter perguntado "A senhora é casada?!", tê-la "salvo" para os seus experimentos ginecológicos no bloco $10 .^{31}$

No transcurso da argumentação Welzer inverte a questão. Digno de esclarecimento é saber por que alguém recusou ou evitou participar dos fuzilamentos. O crime é absolutamente normal por que as coordenadas decisivas haviam sido dinamizadas já em 1933. Bar-Tal (1994, p. 53-69) interpretou a desumanização das vítimas como pré-condição para os crimes do Nacional-Socialismo, como é usual em todo genocídio. Membros do batalhão policial 45 negaram qualquer sentimento de culpa no Tribunal. Assim, a questão a ser respondida, para todos os perpetradores diretos, seria: como esse processo de desumanização de vítimas prescritas tornou-se realidade? E, foi essa fronteira moral construída entre perpetradores e "arianos", de um lado e os designados para serem vítimas fatais, consistentemente efetiva? E por que, se essa fronteira contradiz o bom senso?

O experimento de Milgram (Id., Ibid., p. 53-69) e as variações de seus arranjos experimentais estão no centro das argumentações de Welzer, bem como de Browning, Newman e Chirot/McCauley ${ }^{32}$. Considerando-se que a objeção fundamental a esses experimentos é de natureza metodológica e que neles os sujeitos da amostra aparecem

${ }^{30}$ Declaração do Dr. Horst Fischer. In: Bundesbeauftragte für die Unterlagen der Staatssicherheit der ehemaligen DDR ( BStU), Ministerium für Staatssicherheit (MfS), ZUV 84, Bd. 36, Stenographische Protokolle, 4. Verhandlungstag, 14.3.1966, Bl. 07 ff.

${ }^{31}$ S. Orthel/ Fels, Transkript S. 30. Cf. ORTHEL/FELS, 1975. Uma transcrição de declarações de testemunhas desse documentário foi processada por estudantes do semestre de inverno 2004/2005, no seminário sobre perpetradores do Nacional-Socialismo organizado por H. Kramer no Departamento de Ciências Sociais da Goethe-Universität Frankfurt.

Latitude, Vol. 1, no2, pp.07-46, 2007. 
como vítimas e, portanto, são enganados sobre o verdadeiro propósito do experimento ${ }^{33}$, não se pode evitar tratá-los criticamente.

A tentativa de Welzer de explicar o holocausto sócio-psicologicamente e, por assim dizer, a partir de um molde, permanece inconsistente. Não convence entender como normalidade o fato de os agentes terem, sob coerções sociais contingentes, tomado a decisão de participar das execuções e depois passarem a matar como um trabalho regular. De fato até Eduard Wirths, em novembro de 1944, após Himmler ter ordenado parar imediatamente com a seleção de judeus transportados para a câmara de gás em Auschwitz-Birkenau, escreveu ter ficado alegre por não precisar mais fazer "esse terrível trabalho" e por ele não mais existir. Que Wirths fale de "trabalho" - ele fala também em outros momentos de "uma tarefa especial", de "uma ordem do Führer" e de uma "luta no Front interno" - não significa que ele compreendia o matar como um trabalho qualquer e que ele tenha perdido a consciência da injustiça ao matar, pois seu suicídio quase um ano mais tarde deixa-se interpretar como admissão de culpa, como foi confirmado por seu então prisioneiro-secretário Langbein.

Mesmo que Welzer rejeite isso expressamente, interpreta o matar, ao longo de suas argumentações, como um processo coletivo quase antropológico, uma vez que a violência estaria presente em todas as sociedades humanas - pelo menos sob o monopólio da violência estatal (WELZER, 2005a, p. 265). Ao se reportar às declarações de antigos membros do batalhão policial 45 , cujas biografias fizeram parte apenas de modo rudimentar de seu livro e sequer foram interpretadas - em que pese a existência, entre eles, de um número enorme de "velhos combatentes" do NSDAP (Id. , p. 91-97) -, ele constata conclusivamente:

"Enquanto indícios autobiográficos e disposições psíquicas poderiam
ser interessantes para esclarecer sobre comportamentos solidários
(",Helferverhalten"), só ajudam a compreender o comportamento de
perpetradores onde o espaço do trabalho de matar for constituído de
modo individual e diferenciado. Em contraste, a disposição
fundamental para a participação em qualquer modo imaginável de

${ }^{32}$ Cf. NEWMAN, 2006: Beyond Situationism. The Social Psychology of Genocide and Mass Killing, in: Kramer, H. (ed): NS-Täter aus interdisziplinärer Perspektive. München, 2006, p. 107120.

${ }^{33}$ S. Thomas von Freyberg (1978) demonstra, a propósito de trabalho de capacitação política, como membros de sindicatos (tomando o lugar de cientistas ao prepararem o arranjo experimental) instrumentalisaram jovens participantes para exibirem o próprio autoritarismo. No pior exemplo, os participantes foram solicitados, durante a exibição de filmes contendo imagens da libertação do campo de concentração Bergen-Belsen, a cantarem a canção popular alemã "Froh zu sein bedarf es wenig" ("é preciso de pouco para estar alegre"), para então, na seqüência do esclarecimento sobre a finalidade do experimento, serem envergonhados com a própria prontidão para a obediência e dependência diante da autoridade.

Latitude, Vol. 1, no2, pp.07-46, 2007. 
exclusão, privação e roubo não constitui um fenômeno individual e psicológico e isso vale também para a construção de disposições coletivas para matar, mesmo que essas mortes sejam executadas por perpetradores individuais." (Ibid., p. 262).

Se passarmos em revista o comportamento dos médicos da SS em Auschwitz, os quais, segundo a leitura de Welzer, tomaram parte no genocídio de modo habitual e profissional, atuando na seleção rotineira da rampa, nos barracos de doentes e nas inspeções ("Lagerappell") $)^{34}$, mas ao mesmo tempo salvaram um ou outro prisioneiro funcional ("Funktionshäftlinge") da morte certa ${ }^{35}$, então torna-se visível a impossibilidade de generalizar as argumentações de Welzer. Ainda que ele posteriormente procure relativizar o escamoteamento do individual e da moral, quando afirma que quem matou decidiu-se a isso e é, portanto, pessoalmente responsável (WELZER, 2005b, p. 10), sua leitura não pode ser, com essa mera relativização, compensada.

De modo tão simplista não se pode esclarecer "por que pessoas tão normais tornam-se assassinas". Os dois lados de suas argumentações precisam aqui serem vistos a partir de um outro foco, precisam de correções e de complementações:

1. Se existiu de fato uma "nova moral" no Nacional-Socialismo, então ela surgiu de uma associação paramilitar da SS, através de normas orientadoras formuladas por Himmler, enquanto moral interna ("Binnenmoral") da instituição e de sua autoproclamada elite. Essa moral interna ("Binnenmoral") corresponde à moral da máfia. Sua especificidade reside em vincular os objetivos da "luta racial" do partido com as missões de segurança estatal e - no início exclusivamente - com a função de proteger Hitler; em virtude de oportunidades estruturais, vincula-se também a golpistas radicais de direita legalmente "empoderados" e em concorrência tanto com a organização partidária da SA como com as forças armadas alemãs ("Wehrmacht"). Uma "liberação das estruturas de ação", como Michael Wildt constatou em relação ao corpo de liderança da RSHA, somente pôde se afirmar a partir da perspectiva de uma autoridade pública envolvida com rotinas burocráticas e controles legais. As medidas daí decorrentes provocaram também mudanças no contexto de ação de administradores, policiais e agentes criminais que foram cooptados por Best e pelo SD para atuarem na Gestapo, mas não no contexto de políticos da alta hierarquia da SS, como o próprio

\footnotetext{
${ }^{34}$ As inspeções ("Lagerappell") eram feitas em Auschwitz duas vezes por dia e permitiam aos guardas da SS verificar o número de prisioneiros, controlá-los, praticar punições, torturas e exercer intimidações. Os prisioneiros tinham que se alinhar na praça das inpeções ("Appellplatz"), que era também cenário para execuções públicas (N.T.).

${ }^{35}$ Por esta razão, concordo com Benz (2004), que salvadores e perpetradores do holocausto não se diferenciam necessariamente com relação às suas estruturas psíquicas. Cf. a posição contrária, de natureza moral-psicológica de Monroe, 2006 e Staub, 2003.
}

Latitude, Vol. 1, no2, pp.07-46, 2007. 
Best, Heydrich e Himmler. Com o crescente aumento do poder da SS, a "lei que regula a ação" passou a ser definida a partir das medidas estalecidas pela moral interna ("Binnenmoral") e criminosa da SS. Essa moral foi formada a partir de uma "consciência nacional-socialista". ${ }^{36}$ Acima foram descritas as estruturas de relações mafiosas concernentes a uma parte dos perpetradores diretos ("Direkt-Täter"), partindo-se da realidade de sua participação no genocídio industrializado - perspectiva que se opõe à de Wildt. A característica específica da SS enquanto "elite racial" paramilitar é que ela pôde ser a executora de uma "luta racial" por ela mesma definida e, isso, através do enfraquecimento ("Entmachtung") parcial da SA (entre outros, com o assassinato de Röhm em 1934) e de uma simultânea suposta fundamentação científica do antisemitismo do barulho ("Radau Anti-Semitismus") da SA, além da tentativa, a partir do início da guerra, de funcionar militarmente tão bem como a Wehrmacht. Depois que uma unidade de ataque da SS comandada por Theodor Eike, instrutor-chefe de todos os comandantes dos campos de concentração, quase foi destruída perto de Leningrado, ele iniciou a expansão da "luta racial" dentro do próprio exército (ORTH, 2000, p. 201): No inverno de 1941 todos os soldados da Wehrmacht identificados como "judeus ou ciganos miscigenados" foram removidos do front orienta $l^{37}$. Essa iniciativa de Eike deve ter alimentado a fantasia de que a derrota dessa divisão de armas da SS nada tinha a ver com a superioridade militar do inimigo soviético, com a insuficiente formação e deficitária munição da SS, mas sim com a sabotagem do "inimigo racial" dentro da própria Wehrmacht. A "elite ariana" da SS não pode ter fracassado militarmente. Essa dupla rivalidade da SS é um elemento da radicalização identificada por Hans Mommsen.

2. Ulrich Oevermann demonstrou que a orientação para a ação do médico da SS Hans Münch era baseada em um modelo de intervenção médica que levou completamente ao fracasso da socialização profissional - e de seu fundamento moral -, para não dizer que se transformou em seu oposto (OEVERMANN, 2000). Permanece por enquanto aberto se Münch é um caso típico em relação a outros médicos da SS que tomaram parte no genocídio. Parece haver grandes intersecções entre Wirths, Fischer, Mengele, Delmotte e Lucas ${ }^{38}$ no que concerne tanto ao desenvolvimento biográfico quanto às influências políticas e específicas de classe, de tal modo que esses casos deixam se caracterizar a partir de Münch. Mas esse modelo de intervenção médica não

${ }^{36} \mathrm{O}$ que não significa dizer que ela tenha se limitado à SS. Hermann Göring, por exemplo, argumentou uma vez, contra as preocupações morais de outrem: "Minha consciência se chama Adolf Hitler! ". Para a análise da transformação da consciência "normal" em consciência étnica, alemã e nazista cf. Koonz 2003.

37 É o caso de todos os "judeus estreitamente relacionados" ("jüdisch versippten"), como do conhecido escritor e compositor de canções religiosas Jochen Klepper. Em seus diários de guerra ele descreve como superiores e camaradas procuraram mantê-lo em posição subordinada na companhia. Um ano após a sua expulsão da Wehrmacht, isolado entre membros da Igreja da Confissão (Bekennende Kirche) em Berlim, cometeu, juntamente com a esposa e a filha mais velha, sucicídio. Cf. Klepper, 1958.

Latitude, Vol. 1, no2, pp.07-46, 2007. 
pode ser transportado para outros acadêmicos ou para antigos funcionários da área criminal e policiais que tomaram parte no genocídio. Na descrição de Welzer a socialização mecânica para matar deixa-se interpretar como mera formação técnica para puxar o gatilho. Mas os generais da SS não recrutaram para os batalhões policiais cidadãos comuns, nem especialmente fanáticos anti-semitas ou "velhos combatentes" partidários, nem camponeses, açougueiros, professores, floristas ou vencedores de concursos de associações, mas homens que se formaram para serem policiais ou funcionários criminais e que, em parte, considerando-se a sua idade avançada, só condicionalmente poderiam ser engajados no front (Cf. WELZER, 2005a, p. 91-97). De sua socialização profissional faz parte, evidentemente, a formação em técnicas para impor o uso de violência física contra delinquentes relutantes, persegui-los e prendêlos. Eles tiveram também um treinamento regular para fuzilar. Um autoritarismo orientado para a subserviência diante do Estado já devia ter se formado entre eles ainda na República de Weimar; já estavam, pois, predispostos a assumirem lugar de comando em órgãos executivos estatais. ${ }^{39}$

A desumanização das vítimas precisou ser, no entanto, na perspectiva dos perpetradores diante de crianças, mulheres e homens tratados como "seres inferiores" ("Untermenschen"), "números" (Münch) ou como "mercadorias" (Stangl), "insetos", "portadores de moléstias", permanentemente construída contra a percepção realista de que as pessoas que eles assassinavam em nada diferiam daquelas de seu próprio contexto social e civil. Assim respondeu Münch à questão colocada sobre o que mais o impressionou na seleção da rampa ("Rampenselektion"):

"Mm: e äh lá cada um (...) sentiu e (...) fez sua experiência de modo diferente. A maioria naturalmente estava a isso obri... ${ }^{40}$ e eu me coloco também entre eles (...) incrivelmente, impressionante crianças (...) e mães (...) (suspira levemente) quando eram arrancados do grupo ao qual pertenciam, não é (...) mas por que elas com freqüência (...) ou com muita freqüência estavam com as mães ou com as tias ou com algo, eram fáceis de serem acalmadas (...) mas

\footnotetext{
${ }^{38}$ Sejam citados também outros médicos da SS em Auschwitz a partir de 1942, como Thilo, Kitt e Rhode, que não foram aqui explicitamente apresentados.

${ }^{39}$ Uma visão anti-semita e uma "educação para a dureza" já constavam das diretrizes para a formação dos policiais de reserva nos batalhões, em 23.01.1940 (BA R 19/308 apud Kugler 2004, p. 140). Um Regulamento de 15.11 .1940 obrigava todos os membros da polícia alemã, a verem, durante o inverno, o filme "doce judeu" ("Jud Süß"). Cf. a respeito Deutschkron, 1996, 2003, p. 140. Já em 21.2.1933, Göring publicou um decreto endereçado à polícia: "os policiais que, em exercício de seus deveres, fizerem uso de armas de fogo, serão por nós protegidos, independentemente das conseqüências desse uso".(Cf. SAHL, 1990, p. 206).

${ }^{40}$ Münch parece querer dizer, em alemão, "dazu gezwungen" (obrigado a isso). No entanto, não pronuncia a palavra até o fim, apenas a sugere. A tradução, aqui, portanto, é apenas uma possibilidade, porém bastante provável (N.T.)
}

Latitude, Vol. 1, no2, pp.07-46, 2007. 
com que (...) (suspira) ach com (...) ingenuidade ou como a gente diz (...) com que criancice elas marchavam (...) isso era algo (...) isso era para mim, isso era um (...) apesar do meu teor alcoólico ("Alkoholnebel"), não é, ou talvez (...) me tocava de modo ainda mais concentrado. ${ }^{41}$

O trecho acima, extraído de um documentário da televisão holandesa sobre Eduard Wirths em 1975, é esclarecedor sob muitos aspectos: 1. Münch "confessa", mais uma entre tantas vezes na esfera pública alemã, sua participação direta na seleção da rampa e com isso no assassinato de judeus deportados, sem que esse aspecto de sua fala tenha sido percebido por alguém e levado a um processo contra ele; 2. Essa "confissão" vem emoldurada pela sugestão de inimputabilidade por abuso de álcool. Também nas entrevistas concedidas a Robert J. Lifton entre 1977 e 1981 Münch salientou sempre ter tido, desde a juventude, um "problema com o álcool", que teria superado com a idade avançada; 3. e, em relação à tentativa de esclarecimento dos motivos dos assassinos, a fundamental observação: Münch está impressionado com a "ingenuidade" e com a "criancice" com a qual crianças, mães e mulheres idosas ("tias mais velhas") marchavam para a câmara de gás, para a morte, com bebês, ao lado de homens idosos e jovens com deficiências físicas visíveis. Desde o início uma instância de censura moral, da qual ele ainda dispõe, impede Münch de dizer o que de fato pensa: ele ficou impressionado com a burrice de ver pessoas marchando para a morte somente a partir de um comando. Mesmo o próprio Münch tendo participado das manobras da SS de ocultar das pessoas que elas seriam assassinadas quando se encontravam a caminho da câmara de gás e de alimentar nelas a expectativa de que receberiam "finalmente uma ducha, algo para comer e beber", é incapaz de compreender essa situação complementar, a partir da perspectiva das vítimas. Apesar de um atestato médico confirmando um QI prémórbido com a pontuação de 124 o perpetrador Münch é tão burro que não pôde se colocar no lugar das vítimas, isso em 1975 e mais tarde, em 2001, no ano de sua morte. Münch é, neste sentido, tão burro como Hannah Arendt afirmou ser Eichmann. Essa forma de burrice nada tem a ver com formação ou com qualificação, não é específica de classe ou de gênero e não pode ser reduzida à atual fórmula, tão em moda, da "inteligência emocional". Horkheimer considerou, citando Else Frenkel-Brunswick no prefácio à obra Authoritarian Personality, de modo pessimista a possibilidade de esclarecimento político, já que não se pode fazer "um povo inteiro", notadamente o alemão, se sentar no divã do psicanalista (ADORNO et al., 1950). Além disso é próprio da socialização profissional de policiais, unidades militares especiais e em medida menor da qualificação de soldados regulares, reprimir todo impulso para a empatia com pessoas que, no exercício de suas tarefas, são pegas, imobilizadas ou eliminadas pela morte. A descrita forma de burrice é, neste contexto, metodicamente treinada; não é toda pessoa que é boa o suficiente para esse tipo de socialização profissional, mas

${ }^{41}$ Cf. ORTHEL/FELS, 1975, Transkript, pp-10-11 (Vide Nota 28).

Latitude, Vol. 1, no2, pp.07-46, 2007. 
quem se sente atacado ou ameaçado, desliga-se da empatia com o inimigo para salvar a própria pele). Uma exceção à essa regra e exemplo para o tipo de masoquismo patológico parecem ser aquelas mulheres maltratadas que sempre retornam para os homens que as espancam a ponto de serem hospitalizadas (Cf. BRÜCKNER, 1983).

Como vimos no exemplo dos médicos da SS aqui apresentados e discutidos, biograficamente a tese da excepcionalidade alemã é possível de ser provada. Se resumirmos, mais uma vez, os esboços das biografias dos perpetradores sob o aspecto da socialização política, fica evidente que entre eles ninguém existiu que fosse proveniente da esquerda radical e que tivesse se demonstrado, durante a República de Weimar, "apto à violência" ("gewaltbereit) por uma revolução ou por um golpe sangrento. $\mathrm{O}$ oportuninismo político em sentido estrito, como se deu mais tarde maciçamente e com o apoio estatal, quando nazistas leais foram transformados em cidadãos adaptados na República Democrática Alemã (DDR), não desempenhou nenhum papel na transformação de indivíduos, durante a Segunda Guerra Mundial, em assassinos em massa. Foram as instâncias de socialização políticas nacionais e antisemitas do caminho excepcional alemão (deutscher Sonderweg), os ressentimentos contra o fracasso da Primeira Guerra Mundial, a "vergonha de Versailles" fixada pela burguesia letrada, a adjacente mobilidade ascendente e descendente de camadas sociais que se aglutinavam nos círculos radicais de direita ao fim da primeira guerra que levaram, após 1933, a socialização formal das gerações mais jovens de perpetradores do holocausto a uma posição de destaque profissional - tudo isso foi central para a formação ideológica e prática da "loucura racial" do Nacional-Socialismo.

\section{Bibliografia}

ADORNO, Theodor W. Else Frenkel-Brunswik, Daniel J. Levinson, R. Nevitt Sanford: The Authoritarian Personality. New York, 1950.

ADORNO, Theodor W. Erziehung nach Auschwitz. In: ders., Kulturkritik und Gesellschaft II. Eingriffe - Stichworte, Gesammelte Schriften 10-2, hrsg. Von Rolf Tiedemann. Frankfurt am Main S. 674-690, 1977.

. Erziehung zur Mündigkeit. Vorträge und Gespräche mit Hellmut Becker 1959-1969, hrsg. Von Gerd Kadelbach. Frankfurt am Main, 1970.

Kultur und Culture, Vortrag, In: Hessische Hochschulwochen für staatswissenschaftliche Fortbildung, 29. Juni bis 19. Juli 1958. Bad Wildungen, Bad Homburg v. d. Höhe, 23. Band, S. 246-259, 1959.

Latitude, Vol. 1, no2, pp.07-46, 2007. 
. Schuld und Abwehr. In: POLLOCK, Friedrich (Hg): Gruppenexperiment. Ein Studienbericht. Frankfurt am Main, 1955.

Kulturkritik und Gesellschaft I. In: Prismen, Frankfurt am Main. (1955) 1977.

ALTEMEYER, Robert Anthony: Right-wing Authoritarianism. Manitoba, Winnipeg 1981.

. The other authoritarian personality. In: ZANNA, M. (Ed.). Advances in Experimental Social Psychology. №30, pp. 47-92, 1998.

ALY, Götz. Hitlers Volksstaat. Raub, Rassenkrieg und nationaler Sozialismus, Frankfurt am Main, 2005.

. Alles wird flott und freudig aufgenommen. Stefan Koldehoff untersucht die NS-Geschäfte mit geraubten jüdischen Kunstwerken, In: Die Zeit, $\mathrm{n}^{\mathrm{o}}$ 10, p.45,4 mar.2010.

AMÉRY, Jean. Jenseits von Schuld und Sühne. Bewältigungsversuche eines Überwältigten, (1966). München, 1990.

ASHKENASI, Abraham: Neonazismus in Deutschland. Deutschland - unverkennbar und wiedervereinigt. In: KRAMER, Helgard. Die Gegenwart der NS-Vergangenhei. Berlin: Wien S. 336-346, 2000.

BAR-TAL, Daniel. The Delegitimization of Jews in Germany 1933-1945. A Case of Group Beliefs. In: KULKE, Christine; LEDERER, Gerda (Hg.). Der gewöhnliche Antisemitismus, Pfaffenweiler, S. 53-69, 1994.

BENZ, Wolfgang (Hg), Überleben im Dritten Reich. Juden im Untergrund und ihre Helfer. München, 2003.

.Was ist Antisemitismus? Band 455 der Schriftenreihe der Bundeszentrale für politische Bildung. München ,2004.

.Zuviel versprochen: Breloer hat Speers Mythos nicht entzaubert, In: Kramer, H.(ed): NS-Täter in interdisziplinärer Perspektive. München, pp. 135-142, 2006.

BEISCHL, Konrad. SS-Standortarzt Dr. Eduard Wirths. In: Kramer, H. (ed): NS-Täter in interdisziplinärer Perspektive. München, pp. 171-196, 2006.

Dr. med. Eduard Wirths und seine Tätigkeit als SS-Standortarzt im KL Auschwitz, Würzburg, 2005.

BERG, Nicolas. Die Lebenslüge vom Pathos der Nüchternheit. Subjektive jüdische Erinnerung und objektive deutsche Zeitgeschichtsforschung: Josef Wulf, Martin Broszat und das Institut für Zeitgeschichte in den sechziger Jahren. In: Süddeutsche Zeitung, S. 14, 16 jul.2002,

Latitude, Vol. 1, no2, pp.07-46, 2007. 
BÖLLINGER, Lorenz. Repression, Externalization, Denial - How Murderers Deal with their Crimes. In: Kramer, H. (Org.). NS-Täter aus interdisziplinärer Perspektive. München, pp.95-106, 2006.

BONSS, Wolfgang und Erich Fromm. Arbeiter und Angestellte am Vorabend des Dritten Reiches. Eine sozialpsychologische Untersuchung. Stuttgart, 1980.

BROSZAT, Martin (Hg.). Kommandant in Auschwitz, autobiographische aufzeichnungen des Rudolf Höss. München, pp. 273-279, 2004.

BROWNING, Christopher. Ideology, Culture, Situation, and Disposition. Holocaust Perpetrators and the Group Dynamic of Mass Killing. In: GOTTWALD, Alfred; KAMPE, Norbert; KLEIN, Peter (Hg.). NS-Gewaltherrschaft. Beiträge zur historischen Forschung und juristischen Aufarbeitung. Berlin, S. 66-76, 2005.

BRÜCKNER, Margrit. Die Liebe der Frauen. Über Weiblichkeit und Misshandlung. Frankfurt am Main, 1983.

BRUHNS, Wibke.Meines Vaters Land. Geschichte einer deutschen Familie. München 2003.

BURRIN, Phillippe: Warum die Deutschen? Antisemitismus, Nationalsozialismus, Genozid. Berlin 2004.

CHIROT, Daniel and CLARK R. McCauley: Why not kill them all? The logic and prevention of mass political murder. Princeton, N.J., 2006.

CZARNOWSKI, Gabriele. Zwischen Germanisierung und Vernichtung. Verbotene polnisch-deutsche Liebesbeziehungen und die Rekonstruktion des Volkskörpers im Zweiten Weltkrieg. In: KRAMER, Helgard. Die Gegenwart der NSVergangenheit. Berlin, Wien, S. 295-303, 2000.

CESARANI, David. Adolf Eichmann. Bürokrat und Massenmörder. Berlin, 2004.

CURILLA, Wolfgang. Die deutsche Ordnungspolizei und der Holocaust im Baltikum und in Weißrussland 1941-1944. Paderborn, 2006.

DABAG, Mirhan. Modern Societies and Collective Violence. The Framework of Interdisciplinary Genocide Studies. In: KINLOCH, G.C.; MOHAN, R.P. (Eds.). Genocide. Approaches, Case Studies and Responses. New York, 2005.

DEUTSCHKRON, Inge. Sie blieben im Schatten. Ein Denkmal für stille Helden. Berlin (1996), 2003.

DEDERICHS, Mario R. Heydrich. Das Gesicht des Bösen. München; Zürich, 2006.

DIRKS, Christian. Karrieresprung Vernichtungslager. Dr. Horst Fischer in Auschwitz. In: KRAMER, Helgard (Org.). NS-Täter aus interdisziplinärer Perspektive. München, p.143-170, 2006.

Latitude, Vol. 1, no2, pp.07-46, 2007. 
DOERRY, Martin. Mein verwundetes Herz. Das Leben der Lilli Jahn 1900-1944. Bonn, 2004.

DUBIEL, Helmut. Niemand ist frei von der Geschichte. Die nationalsozialistische Herrschaft in den Debatten des Deutschen Bundestages. München, 1999.

DUCKITT, John and FISHER, Kirstin. The impact of social threat on worldview and ideological attitudes. Political Psychology. Vol.: 24, pp. 199-222, 2003.

DÜSTERBERG, Rolf. Hanns Johst, Der Barde der SS. Paderborn, 2004(a).

DÜSTERBERG, Rolf. Mein Reichsführer, lieber Heini Himmler! In: Die Zeit, n12, S. 82, 11 mar. 2004(b).

EVANS, Richard J. The Coming of the Third Reich. London, p. XXVIII-XXIV, 2003.

FAHRENBERG, Jochen und STEINER, John M. Autoritäre Einstellungen und Statusmerkmale von ehemaligen Angehörigen der Waffen-SS und SS und Wehrmacht. Eine erweiterte Reanalyse der 1970 publizierten Untersuchung. Kölner Zeitschrift für Soziologie und Sozialpsychologie, 52 (2), S. 329-348, 2000.

FELDMAN, Stanley. Enforcing Social Conformity: A Theory of Authoritarianism. Political Psychology. Vol. 24, no 1, pp. 41-76, 2003.

FREI, Norbert. Auschwitz und Holocaust. Begriff und Historiographie. In: Hanno Loewy (Hg.). Holocaust. Die Grenzen des Verstehens. Eine Debatte über die Besetzung der Geschichte. Reinbek, S. 101-109, 1992.

FREVERT, Ute. Ehrenmänner. Das Duell in der bürgerlichen Gesellschaft. München, 1991.

FRIEDLANDER, Henry. Der Weg zum NS-Genozid. Von der Euthanasie zur Endlösung. Berlin, 1997.

FROMM, Erich. Sozialpsychologischer Teil. In: HORKHEIMER, Max (Hg). Autorität und Familie. Paris, 1936.

FUNKE, Hajo. Wir haben sechs Juden erschossen. So steht es im Tagebuch. Ich weiß es nicht in Schuld verstrickt, die nicht tilgbar ist? In: KRAMER, Helgard. Die Gegenwart der NS-Vergangenheit. Berlin, Wien, S. 255-277, 2000.

GADAMER, Hans-Georg. Im Gespräch mit Catherine Hürzeler. In: Das Argument, 2004.

GOLDENSOHN, Leon. Die Nürnberger Interviews. Gespräche mit Angeklagten und Zeugen. Düsseldorf ,2005.

GROSSMANN, Atina. The new woman, the new family and the rationalization of sexuality. The sex reform movement in Germany 1928 to 1933. New Brunswick ,1984.

Latitude, Vol. 1, no2, pp.07-46, 2007. 
GRÜNBERG, Kurt. Trauma-Tradierung. Überlebende der Shoah und ihre Nachkommen in der Bundesrepublik Deutschland. In: KRAMER, Helgard (Ed). NS-Täter aus interdisziplinärer Perspektive. München, p.27-44, 2006.

HAGEMANN, Karen; SCHÜLER-SPRINGORUM, Stefanie (Hg). Heimat-Front. Militär und Geschlechterverhältnisse im Zeitalter der Weltkriege. Frankfurt; New York, 2002.

HAHN, Judith. Grawitz, Gre nzken, Gebhardt. Drei Karrieren im Sanitätsdienst der SS. Berlin, 2008

HERDING, Klaus. Kunst und Alltag im NS-System. Gießen, 1975.

HEUBERGER, Rachel et all.Hinaus aus dem Ghetto. Juden in Frankfurt am Main 18001950. Frankfurt am Main ,1988.

HERBERT, Ulrich. Wer waren die Nationalsozialisten? Typologien des politischen Verhaltens im NS-Staat. In: HIRSCHFELD, Gerhard und JERSAK, Tobias (Hg.). Karrieren im Nationalsozialismus. Funktionseliten zwischen Mitwirkung und Distanz. Frankfurt am Main, 2004.

.Best. Biographische Studien über Radikalismus, Weltanschauung und Vernunft, 1903-1989. Bonn, 2001.

.Eine. Führerentscheidung zur 'Endlösung? Neue Ansätze in einer alten Diskussion. In: Neue Zürcher Zeitung, 14./15.3.1998.

HOLZ, Klaus. Nationaler Antisemitismus, Wissenssoziologie einer Weltanschauung. Hamburg, 2001.

HORKHEIMER, Max (Hg): Autorität und Familie, Paris, 1936.

JÄCKEL, Eberhard et all. Der Tod ist ein Meister aus Deutschland. Deportation und Ermordung der Juden. Kollaboration und Verweigerung in Europa. München (2. Aufl.), 1993

JAERISCH, Ursula. Sind Arbeiter autoritär? Zur Methodenkritik politischer Psychologie, Frankfurt am Main, Köln, 1975.

KAMINER, Isidor. Normalität und Nationalsozialismus. In: Psyche, Jg. 51, H. 54, S. 385406, 1997.

KAMPLING, Rainer. Religiöse Motivation der Täter? Annäherungen an eine Fiktion des Entschuldigungsmythos. In: KRAMER, Helgard (Ed). NS-Täter aus interdisziplinärer Perspektive. München, p.243-252, 2006.

KINDERVATER, Angela; RIPPL, Susanne und SEIPEL, Christian (Hg.). Autoritarismus. Kontroversen und Ansätze der aktuellen Autoritarismusforschung. Opladen, 2000.

Latitude, Vol. 1, no2, pp.07-46, 2007. 
KLEE, Ernst. Was sie taten - was sie wurden. Ärzte, Juristen und andere Beteiligte am Kranken- und Judenmord. Frankfurt am Main, 1992.

. Das Personenlexikon zum Dritten Reich. Wer war was vor und nach 1945. Frankfurt am Main (2. Aufl.), 2003.

KLEMP, Stefan. Nicht ermittelt - Polizeibataillone und die Nachkriegsjustiz - Ein Handbuch. Essen, 2005.

KLEPPER, Jochen. Überwindung. Tagebücher und Aufzeichnungen aus dem Kriege. Stuttgart, 1958.

KLÜGER, Ruth. Weiter leben. Eine Jugend. Göttingen, 1993.

KOGON, Eugen. Der SS-Staat. Das System der deutschen Konzentrationslager. München (1946) 1974.

KOONZ, Claudia. The Nazi Conscience. New Haven, 2003.

KRAMER, H. (Ed). NS-Täter aus interdisziplinärer Perspektive. München, p.9-26, 2006.

. Sammelrezension. U. Völklein: Dr. Eduard Wirths, in: H-Soz-u-Kult (onlineRezensionen) url:<http:hsozkult.geschichte.hu-berlin.de/rezensionen/id=8665> Acesso 30 nov. 2006.

. Das 'doppelte Selbst' des SS-Standortarztes von Auschwitz.In: KRAMER, Helgard (Ed). NS-Täter aus interdisziplinärer Perspektive. München, p.197-230, 2006.

. (Ed).Die Gegenwart der NS-Vergangenheit. Berlin, Wien, 2000.

.u.a. Grenzen der Frauenlohnarbeit. Frauenstrategien in Lohn- und Hausarbeit seit der Jahrhundertwende. Frankfurt am Main; New York , p. 154, 1986.

KUGLER, Anita. Scherwitz. Der jüdische SS-Offizier. Köln 2004.

LANGBEIN, Hermann. Menschen in Auschwitz. München, Wien, 1995.

LEDERER, Gerda et all (Hg.). Autoritarismus und Gesellschaft. Trendanalysen und vergleichende Jugenduntersuchungen von 1945-1993. Opladen, 1995.

LIFTON, Robert J. The Nazi Doctors. Medical Killing and the Psychology of Genocide. New York, 1986.

MALLMANN, Klaus-Michael; GERHARD, Paul (Hg): Karrieren der Gewalt. Nationalsozialistische Täterbiographien. Darmstadt, 2004 .

MATTIOLI, Aram. Das faschistische Italien - ein unbekanntes Apartheidsregime. In: Jahrbuch des Fritz-Bauer-Instituts, S. 155-178, 2005.

Latitude, Vol. 1, no2, pp.07-46, 2007. 
MEDICUS, Thomas. Selbstaufklärung. Wehrmacht und Moral. In: Frankfurter Rundschau, S. 8., 6 nov.1999.

MEULEMANN, Heiner. Wertwandel in der Bundesrepublik zwischen 1950 und 1980. Versuch einer zusammenfassenden Deutung vorliegender Zeitreihen. In: OBERNDÖRFER, Dieter; RATTINGER, Hans und SCHMITT, Karl (Hg.). Wirtschaftlicher Wandel, religiöser Wandel und Wertwandel. Folgen für das politische Verhalten in der Bundesrepublik Deutschland, Berlin, 1985.

MEYER, Winfried. Dr. Franz Lucas, Anmerkungen zu einem "weißen Raben“. Vortrag auf der Konferenz. NS-Täter aus interdisziplinärer Perspektive. Freie Universität Berlin, April, 2005.

MOMMSEN, Hans. Probleme der Täterforschung. In: KRAMER, Helgard (Org.): NSTäter aus interdisziplinärer Perspektive. München, p. 425-434, 2006.

Warum hier? Warum wir? Die Deutschen und der Antisemitismus in verschiedenen zeitgeschichtlichen Herangehensweisen. In: Frankfurter Rundschau, S. 16, 16 out. 2004.

. Auschwitz, 17. Juli 1942. Der Weg zur europäischen. Endlösung der Judenfrage. München, 2002.

. Zur Verschränkung traditioneller und faschistischer Führungseliten in Deutschland. In: SCHIEDER, Wolfgang (Hg.): Faschismus als soziale Bewegung. Deutschland und Italien im Vergleich. Göttingen, S. 157-181, 1983.

MONROE, Kristen Renwick. Moral Psychology and Genocide: A Study in Ethical Contrasts During the Holocaust. Paper presented at the Annual Scientific Meeting of the International Society of Political Psychology (ISPP). Barcelona, Spain, July 12-16, 2006.

MOSSE, George L. Das Bild des Mannes. Zur Konstruktion der modernen Männlichkeit, Frankfurt am Main. 1997.

MÜLLER-HILL, Benno. Tödliche Wissenschaft. Die Aussonderung von Juden, Zigeunern und Geisteskranken 1933-1945. Berlin, 1989.

NEIDHARDT, Friedhelm. Helmut K. Anheier und Wolfgang Vortkampf: Konjunkturen der NS-Bewegung. Eine Untersuchung der Veranstaltungsaktivitäten der Münchner NSDAP, 1925-1930. Berlin, 1998.

NEWMAN, Leonard S. Beyond Situationism. The Social Psychology of Genocide and Mass Killing. In: KRAMER, Helgard (Ed). NS-Täter aus interdisziplinarer Perspektive. München, p. 107-120, 2006.

Latitude, Vol. 1, no2, pp.07-46, 2007. 
OESTERREICH, Detlef. Autoritäre Persönlichkeit und Gesellschaftsordnung. Der Stellenwert psychischer Faktoren für politische Einstellungen. Eine empirische Untersuchung von Jugendlichen in Ost und West. Weinheim, 1993.

OEVERMANN, Ulrich. Mediziner in SS-Uniform. Professionalisierungstheoretische Deutung des Falles Münch. In: KRAMER, Helgard (Ed). Die Gegenwart der NSVergangenheit. Berlin/Wien: Philo, S. 18-76, 2000.

ORTH, Karin. Die Konzentrationslager-SS. Sozialstrukturelle Analysen und biographische Studien. Göttingen, 2000.

PAUL, Gerhard et al. Sozialisation, Milieu und Gewalt. Fortschritte und Probleme der neueren Täterforschung. In: GERHARD, Paul; MALLMANN, Klaus-Michael. Karrieren der Gewalt. Nationalsozialistische Täterbiographien, Darmstadt S.1-32, 2004.

GERHARD, Paul. Von Psychopathen, Technokraten des Terrors und 'ganz gewöhnlichen' Deutschen. Die Täter der Shoah im Spiegel der Forschung. In: ders. (Hg.). Die Täter der Shoah. Fanatische Nationalsozialisten oder ganz normale Deutsche?, Göttingen, S. 13-90, 2002.

. Dissens und Verweigerung. In: STEINBACH, Peter; TUCHEL, Johannes (Eds), p.226-248, 2004.

PLATT, Kristin. Perspektiven und Aufgaben der Genozidforschung. Vom 'sozialen Testament' zum Problem der globalen Enthistorisierung politischer Prozesse. In: Zeitschrift für Genozidforschung, Jg. 6, Heft 1, 2005.

POLLOCK, Friedrich. Gruppenexperiment: Ein Studienbericht. Frankfurter Beiträge zur Soziologie. Frankfurt, 1955.

SAHL, Hans. Memoiren eines Moralisten. Zürich ,1990.

SANDER, Peter. Verwaltung des Krankenmordes. Der Bezirksverband Nassau im Nationalsozialismus. Gießen ,2003.

SCHIVELBUSCH, Wolfgang. Zur Lage der Frankfurter Intelligenz in den 20er Jahren. Frankfurt am Main, 1983.

SCHÜTZE, Yvonne. Die gute Mutter. Zur Geschichte des normativen Musters Mutterliebe. Bielefeld 1986.

SCHWAN, Gesine. Politik und Schuld. Die zerstörerische Macht des Schweigens, Frankfurt am Main. (3. Aufl.), 2001.

SCHWARTZ, Johannes. Handlungsoptionen von KZ-Aufseherinnen. Drei alltags-und geschlechter-geschichtliche biographische Fallstudien. In: KRAMER, Helgard (Ed.). NS-Täter aus interdisziplinärer Perspektive. München, p.349-374, 2006.

Latitude, Vol. 1, no2, pp.07-46, 2007. 
SERENY, Gitta. Das Ringen mit der Wahrheit. Albert Speer und das deutsche Trauma, München 1995(a) Albert Speer. His Battle with Truth. London, 1995.

. Am Abgrund. Gespräche mit dem Henker Franz Stangl und die Morde von Treblinka, München 1995(b) (Into that Darkness. From Mercy Killing to Mass Murder, London 1974).

SOLF, Ursula. Wenn das Recht im Auge des Betrachters liegt: NS-Täter aus juristischer Perspektive. In: KRAMER, Helgard (Ed). NS-Täter aus interdisziplinärer Perspektive. München, pp.79-94, 2006.

STAUB, Erving. The Psychology of Good and Evil. Why Children, Adults, and Groups Help and Harm Others. Cambridge, 2003.

STEINBACH, Peter et al. Widerstand gegen die nationalsozialistische Diktatur 1933-1945. Schriftenreihe: Bundeszentrale für politische Bildung, Bd. 438, Bonn, 2004.

STEPPE, Hilde (Hg.). Krankenpflege im Nationalsozialismus. Frankfurt am Main, 1993.

STEPPE, Hilde at al (Hg). Ich war von jeher mit Leib und Seele gerne Pflegerin. Über die Beteiligung von Krankenschwestern an den Euthanasie - Aktionen in MeseritzObrawalde. Frankfurt ,1999.

VÖLKLEIN, Ulrich. Dr. med. Eduard Wirths: Ein Arzt in Auschwitz. Eine Quellenedition, Norderstedt, 2005.

. Der Judenacker. Eine Erbschaft, Gerlingen ,2001.

. Josef Mengele. Der Arzt von Auschwitz, Göttingen, 2000.

VOLKOV, Shulamit. Antisemitismus als kultureller Code. Zehn Essays. München, 2000.

WEINDLING, Peter. 'Mustergau' Thüringen. Rassenhygiene zwischen Ideologie und Machtpolitik. In: FREI, Norbert (Hg.). Medizin und Gesundheit in der NS-Zeit. Sondernummer der Vierteljahrshefte für Zeitgeschichte. München, S.81-97, 1991.

WELZER, Harald. Täter. Wie aus ganz normalen Menschen Massenmörder werden, Frankfurt am Main, 2005(a).

. Und beim nächsten Mal ist es schon viel einfacher. In: Berliner Zeitung, Magazin, S. 10f., 10./11 agos.2005(b).

. Die Seele gehört nicht mir. Ein Gespräch mit dem Neurobiologen Gerhard Roth und dem Sozialpsychologen Harald Welzer. In: Die Zeit, S. 36f., 23. fev. 2006.

WILDT, Michael. Generation des Unbedingten. Das Führungskorps des Reichssicherheitshauptamtes. Hamburg, 2002.

Latitude, Vol. 1, no2, pp.07-46, 2007. 
WILLEMS, Susanne. Der entsiedelte Jude. Albert Speers Wohnungsmarktpolitik für den Berliner Hauptstadtbau. Berlin, 2002.

WINKLER, Heinrich August. Die deutsche Gesellschaft der Weimarer Republik und der Antisemitismus - Die Juden als 'Blitzableiter'. In: Wolfgang Benz/Werner Bergmann: Vorurteil und Völkermord, Bonn, S. 341-364, 1997.

ZILLMER, Eric A. et al. The Quest for the Nazi Personality. A Psychological Investigation of Nazi War Criminals, Personality and Clinical Psychological Series, Hillsdale, N.J., 1995. ADORNO - Der Bürger als Revolutionär. Dokumentarfilm von Meinhard Prill und Kurt Schneider. Deutschland, 2003.

ÄRZTE UNTER DEM HAKENKREUZ. Dokumentarfilm. Regie: Christopher Paul, Christian Feyerabend und Daniela Gieseler, Deutschland 2003, 132 min.

DR. EDUARD WIRTHS - STANDORTARZT VON AUSCHWITZ. Dokumentarfilm von Hans Fels und Roland Orthel. Niederlande, 1975, 60 min. Transkript s.Disponibilidade: berlin.de/soziologie/kongress_kramer/diskussion/transkript.pdf. >

BUNDESBEAUFTRAGTE FÜR DIE UNTERLAGEN DER STAATSSICHERHEIT DER EHEMALIGEN DDR (BStU), Ministerium für Staatssicherheit (MfS).

Latitude, Vol. 1, no2, pp.07-46, 2007. 